\title{
COOLPEACE SYLLABI OF DISCIPLINES
}

Supported by a grant from Iceland, Liechtenstein and Norway

Finantat prin fonduri donate de Islanda, Liechtenstein si Norvegia

I.

\begin{tabular}{|c|c|c|c|c|}
\hline \multicolumn{2}{|c|}{ Course title } & \multicolumn{2}{|c|}{ NORWEGIAN LANGUAGE } & \\
\hline \multicolumn{5}{|l|}{ II. } \\
\hline \multicolumn{5}{|c|}{$\begin{array}{c}\text { Course structure } \\
\text { (Number of hours per } \\
\text { summer school session) }\end{array}$} \\
\hline Level & Lecture & Seminar & $\begin{array}{c}\text { Practical } \\
\text { course }\end{array}$ & $\begin{array}{c}\text { Summer school } \\
\text { year }\end{array}$ \\
\hline A1 & 9 & 9 & & $1^{\text {st }}$ \\
\hline
\end{tabular}

III.

\begin{tabular}{|l|l|c|c|}
\hline $\begin{array}{l}\text { Optionality } \\
\text { category }\end{array}$ & Imposed & Optional & Freely chosen \\
\hline & & $\mathrm{X}$ & \\
\hline
\end{tabular}

IV.

\begin{tabular}{|l|l|l|l|l|}
\hline \multicolumn{5}{|c|}{ Supervisor } \\
\hline & \multicolumn{1}{|c|}{ Lecture } & \multicolumn{1}{|c|}{ Seminar } & Application & Project \\
\hline Name & Crina Leon & Crina Leon & & \\
\hline Institution & $\begin{array}{l}\text { Alexandru Ioan } \\
\text { Cuza University } \\
\text { of Iaşi }\end{array}$ & $\begin{array}{l}\text { Alexandru Ioan } \\
\text { Cuza University } \\
\text { of Iaşi }\end{array}$ & & \\
\hline Department & $\begin{array}{l}\text { Faculty of } \\
\text { Letters }\end{array}$ & $\begin{array}{l}\text { Faculty of } \\
\text { Letters }\end{array}$ & & \\
\hline $\begin{array}{l}\text { Scientific } \\
\text { title }\end{array}$ & Ph.D. & Ph.D. & & \\
\hline \multirow{3}{*}{ Position } & $\begin{array}{l}\text { Scientific } \\
\text { researcher } \\
\text { Teacher of } \\
\text { Norwegian }\end{array}$ & $\begin{array}{l}\text { Scientific } \\
\text { researcher } \\
\text { Teacher of } \\
\text { Norwegian }\end{array}$ & & \\
\hline
\end{tabular}

V. 


\begin{tabular}{l}
\hline Objectives \\
\hline The course aims to develop the students' ability to understand, express \\
and interpret thoughts, feelings and facts both orally and in writing in a \\
variety of socio-cultural contexts, in the Norwegian language. According \\
to the Common European Framework of Reference for Languages the \\
linguistic level reached is A1.
\end{tabular}

VI.

\begin{tabular}{|c|c|}
\hline Course structure & \multirow{2}{*}{$\begin{array}{l}\text { No. } \\
\text { hours }\end{array}$} \\
\hline VI.1. Lectures & \\
\hline $\begin{array}{l}\text { Lecture 1: The linguistic situation in Norway. Introducing oneself. } \\
\text { Asking questions. }\end{array}$ & 1 \\
\hline $\begin{array}{l}\text { Lecture 2: Asking for information regarding address, age, spoken } \\
\text { languages. }\end{array}$ & 1 \\
\hline $\begin{array}{l}\text { Lecture 3: Expressing time. The daily programme. The days of the } \\
\text { week. }\end{array}$ & 1 \\
\hline $\begin{array}{l}\text { Lecture 4: Giving and asking for food and drink. Telling one's } \\
\text { preferences. }\end{array}$ & 1 \\
\hline Lecture 5: Telling about one's activities. & 1 \\
\hline Lecture 6: Communicating at the post office, bank, library etc. & 1 \\
\hline $\begin{array}{l}\text { Lecture 7: Talking about weather. The months of the year and the } \\
\text { seasons. Filling in a form. }\end{array}$ & 1 \\
\hline $\begin{array}{l}\text { Lecture 8: Asking and giving information in a shop. Asking about } \\
\text { colours, sizes and prices. }\end{array}$ & 1 \\
\hline Lecture 9: Final evaluation. & 1 \\
\hline Total: & $\begin{array}{c}9 \\
\text { hours }\end{array}$ \\
\hline \multicolumn{2}{|l|}{ VI.2. Seminar } \\
\hline $\begin{array}{l}\text { During the seminars the students read and translate the lessons } \\
\text { and do exercises based on the grammar and vocabulary acquired } \\
\text { during the lectures. }\end{array}$ & 9 \\
\hline Total: & hours \\
\hline VI.3. Application & \\
\hline VI.4. Project topic (if the case) & \\
\hline
\end{tabular}

VII.

Syllabus outline 


\begin{tabular}{|l|}
\hline \multicolumn{1}{|c|}{ VII.1. Grammar } \\
\hline Verb: tenses (present, future), modal verbs \\
Noun: gender, number, genitive case \\
Pronoun: personal, possessive, interrogative \\
Adjective: agreement of the adjective with the noun, the adjective "liten" \\
Number: cardinal, ordinal \\
Adverb: short and long forms, inversion after an adverb \\
Preposition: verbs with fixed prepositions \\
Article: definite, indefinite \\
\hline \multicolumn{1}{|c|}{ VII.2. Vocabulary } \\
\hline Greetings and goodbyes \\
Introducing oneself \\
Common questions \\
The family \\
The time: clock, seasons, months, days of the week \\
Food and drink \\
At the post office, bank, library \\
The weather \\
Colours \\
Clothes
\end{tabular}

\section{VIII.}

\begin{tabular}{|l|l|}
\hline \multicolumn{1}{|c|}{ References } & \\
\hline Halvorsen, Arne, Dicționar român-norvegian (Rumensk-norsk ordbok), \\
Polirom, Iasii, 2008 \\
Leon, Crina, Dicționar de buzunar norvegian-român/român-norvegian (Norsk- \\
rumensk/rumensk-norsk lommeordbok), Polirom, Iaşi, 2009 \\
Leon, Crina, Ghid de conversație român-norvegian (Rumensk-norsk parlør), \\
Polirom, Iaşi, 2007 \\
Manne, Gerd; Nilsen, Gölin Kaurin, Ny i Norge: tekstbok, Fagbokforlaget, \\
Bergen, 2010 \\
Manne, Gerd; Nilsen, Gölin Kaurin, Ny i Norge: arbeidsbok, \\
Fagbokforlaget, Bergen, 2010 \\
Tomescu Baciu, Sanda, Velkommen! Manual de conversație în limba \\
norvegiană, Polirom, Iaşi, 2010 \\
\hline
\end{tabular}

IX.

\section{Forms of} Methods and techniques used in the
teaching process 


\begin{tabular}{|l|l|}
\multicolumn{1}{|c|}{ activity } & \\
\hline Lecture & Thematic lectures, CD-player, whiteboard, projector. \\
\hline Seminar & Oral and written exercises, reading, translation. \\
\hline Application & \\
\hline Project & \\
\hline
\end{tabular}

$\mathrm{X}$.

\begin{tabular}{|l|l|l|}
\hline Type & $\begin{array}{l}\text { Assessment system (written, } \\
\text { written and oral, oral, others) }\end{array}$ & \\
\hline Exam & $\begin{array}{l}\text { Written examination (for the } \\
\text { lectures) }\end{array}$ & \\
\hline Colloquium & & \\
\hline $\begin{array}{l}\text { Continuous } \\
\text { assessment }\end{array}$ & $\begin{array}{l}\text { Continous assessment (for the } \\
\text { seminars) }\end{array}$ & \\
\hline Project & & \\
\hline
\end{tabular}

I.

\section{\begin{tabular}{|l|l}
\hline Course title & DANISH LANGUAGE
\end{tabular}}

II.

\begin{tabular}{|c|c|c|c|c|}
\hline \multicolumn{5}{|c|}{$\begin{array}{c}\text { Course structure } \\
\text { (Number of hours per } \\
\text { summer school session) }\end{array}$} \\
\hline Level & Lecture & Seminar & $\begin{array}{c}\text { Practical } \\
\text { course }\end{array}$ & $\begin{array}{c}\text { Summer school } \\
\text { year }\end{array}$ \\
\hline A1 & 12 & 6 & & 1 st \\
\hline
\end{tabular}

III.

\begin{tabular}{|l|l|c|c|}
\hline $\begin{array}{l}\text { Optionality } \\
\text { category }\end{array}$ & Imposed & Optional & Freely chosen \\
\hline & & $\mathrm{X}$ & \\
\hline
\end{tabular}

IV.

\begin{tabular}{|l|l|l|l|l|}
\hline \multicolumn{5}{|c|}{ Supervisor } \\
\hline \multirow{2}{*}{ Name } & \multicolumn{1}{|c|}{ Lecture } & \multicolumn{1}{|c|}{ Seminar } & Application & Project \\
& Lucia & Lucia & & \\
& Alexandroae & Alexandroae & & \\
\hline \multirow{3}{*}{ Institution } & University & University & & \\
& College of & College of & & \\
& Nordjylland & Nordjylland & &
\end{tabular}




\begin{tabular}{|l|l|l|l|l|}
\hline Department & $\begin{array}{l}\text { Marketing } \\
\text { Management }\end{array}$ & $\begin{array}{l}\text { Marketing } \\
\text { Management }\end{array}$ & & \\
\hline $\begin{array}{l}\text { Scientific } \\
\text { title }\end{array}$ & AP & AP & & \\
\hline Position & Graduate & Graduate & & \\
\hline
\end{tabular}

V.

\section{Objectives}

The aim of the course is to enable students to function at a basic everyday survival level (basic vocabulary, grammar, morphology, syntax and phonetics).

On completion of the course students should be able to communicate in and understand the language on a number of practical everyday matters. Language learning skills, including autonomous learning and how to approach authentic material, will be developed. Some transferable skills will also be covered.

VI.

\begin{tabular}{|l|c|}
\hline \multicolumn{1}{|c|}{ Course structure } & No. \\
hours
\end{tabular}




\begin{tabular}{|c|c|}
\hline & hours \\
\hline VI.3. Application (if the case) & \\
\hline VI.4. Project topic (if the case) & \\
\hline
\end{tabular}

VII.

\begin{tabular}{|llc|}
\hline \multicolumn{2}{|c|}{ Syllabus outline } \\
\hline \multicolumn{2}{|c|}{ VII.1. Grammar } \\
\hline $\begin{array}{l}\text { Nouns } \\
\text { Verbs }\end{array}$ & Adjectives & Numbers \\
Pronouns & Adverbs & Interjections \\
\hline \multicolumn{2}{|c|}{ Conjunctions } & Prepositions \\
\hline $\begin{array}{l}\text { Phrases, Translation, Dictionary, Keyboard, Radio, TV, Colors, Numbers, } \\
\text { Body, Time, Days, Food, Animals, Places, Objects, Habits, Biking, Clothes, } \\
\text { Nature, Weather, People, Words, Culture, History, Geography, Tips and } \\
\text { Tricks. }\end{array}$ \\
\hline
\end{tabular}

\section{VIII.}

\begin{tabular}{|l|l|}
\hline \multicolumn{1}{|c|}{ References } & \\
\hline Gelbek, Kirsten, Tempo 1, Alfabeta, 2010 \\
Lecocq, Ben, 5 nye emner, Alfabeta, 2011 \\
Slotorup, Fanny and Neel Jersild Moreira, Dansk for DU 3, Alfabeta, 2011 \\
Thorborg, Lisbet and Mayanna J. Riis, På vej til dansk, Forlaget Synope, 201 \\
\hline
\end{tabular}

IX.

\begin{tabular}{|c|c|}
\hline $\begin{array}{l}\text { Forms of } \\
\text { activity }\end{array}$ & $\begin{array}{l}\text { Methods and techniques used in the } \\
\text { teaching process }\end{array}$ \\
\hline Lecture & Thematic lectures, CD player, projector, whiteboard. \\
\hline Seminar & $\begin{array}{l}\text { DRILLS - As a form of repetition, drills enable one to focus } \\
\text { sharply on particular points of grammar, vocabulary, } \\
\text { pronunciation and spelling. } \\
\text { BUZZ GROUPS - Ability to exchange ideas drawn from } \\
\text { their collective abilities, knowledge and experiences. }\end{array}$ \\
\hline Application & $\begin{array}{ll}\text { BRAINSTORMING } & \begin{array}{l}\text { Generating a large number of ideas } \\
\text { as quickly as possible }\end{array} \\
\end{array}$ \\
\hline Project & $\begin{array}{l}\text { Students use their own experience } \\
\text { and creativity to imitate a real life } \\
\text { situation }\end{array}$ \\
\hline
\end{tabular}

X. 


\begin{tabular}{|l|l|l|}
\hline Type & $\begin{array}{l}\text { Assessment system (written, } \\
\text { written and oral, oral, others) }\end{array}$ & \\
\hline Exam & Written & \\
\hline Colloquium & Oral & \\
\hline $\begin{array}{l}\text { Continuous } \\
\text { assessment }\end{array}$ & Written and oral & \\
\hline Project & & \\
\hline
\end{tabular}

I.

\begin{tabular}{|l|l|}
\hline Course title & SWEDISH LANGUAGE \\
\hline
\end{tabular}

II.

\begin{tabular}{|c|c|c|c|c|}
\hline \multicolumn{5}{|c|}{$\begin{array}{c}\text { Course structure } \\
\text { (Number of hours per } \\
\text { summer school session) }\end{array}$} \\
\hline Level & Lecture & Seminar & $\begin{array}{c}\text { Practical } \\
\text { course }\end{array}$ & $\begin{array}{c}\text { Summer school } \\
\text { year }\end{array}$ \\
\hline A1 & 6 & 8 & 4 & $1^{\text {st }}$ \\
\hline
\end{tabular}

III.

\begin{tabular}{|l|l|c|c|}
\hline $\begin{array}{l}\text { Optionality } \\
\text { category }\end{array}$ & Imposed & Optional & Freely chosen \\
\hline & & $\mathrm{X}$ & \\
\hline
\end{tabular}

IV.

\begin{tabular}{|c|c|c|c|c|}
\hline \multicolumn{5}{|c|}{ Supervisor } \\
\hline & Lecture & Seminar & Application & Project \\
\hline Name & $\begin{array}{l}\text { Roxana- } \\
\text { Andreea } \\
\text { Dragu }\end{array}$ & $\begin{array}{l}\text { Roxana- } \\
\text { Andreea } \\
\text { Dragu }\end{array}$ & & $\begin{array}{l}\text { Roxana- } \\
\text { Andreea } \\
\text { Dragu }\end{array}$ \\
\hline Institution & $\begin{array}{l}\text { University of } \\
\text { Bucharest }\end{array}$ & $\begin{array}{l}\text { University of } \\
\text { Bucharest }\end{array}$ & & $\begin{array}{l}\text { University of } \\
\text { Bucharest }\end{array}$ \\
\hline Department & $\begin{array}{l}\text { Faculty of } \\
\text { Foreign } \\
\text { Languages } \\
\text { and } \\
\text { Literatures }\end{array}$ & $\begin{array}{l}\text { Faculty of } \\
\text { Foreign } \\
\text { Languages } \\
\text { and } \\
\text { Literatures }\end{array}$ & & $\begin{array}{l}\text { Faculty of } \\
\text { Foreign } \\
\text { Languages } \\
\text { and } \\
\text { Literatures }\end{array}$ \\
\hline $\begin{array}{l}\text { Scientific } \\
\text { title }\end{array}$ & $\begin{array}{l}\text { M.A. (B.A. in } \\
\text { Philology, }\end{array}$ & $\begin{array}{l}\text { M.A. (B.A. in } \\
\text { Philology, }\end{array}$ & & $\begin{array}{l}\text { M.A. (B.A. in } \\
\text { Philology, }\end{array}$ \\
\hline
\end{tabular}




\begin{tabular}{|l|l|l|l|l|}
\hline & $\begin{array}{l}\text { English- } \\
\text { Swedish) }\end{array}$ & $\begin{array}{l}\text { English- } \\
\text { Swedish) }\end{array}$ & & $\begin{array}{l}\text { English- } \\
\text { Swedish) }\end{array}$ \\
\hline \multirow{4}{*}{ Position } & Teacher of & Teacher of & & Teacher of \\
& Swedish - & Swedish - & & Swedish - \\
& Bridge & Bridge & & Bridge \\
& Language & Language & & Language \\
& Study House & Study House & Study House \\
\hline
\end{tabular}

V.

\section{Objectives}

By the end of this course, students will be able to introduce themselves and others in Swedish, to give and ask for personal information, use numbers in various everyday contexts and speak about daily activities in Swedish.

They will also become acquainted with the basics of Swedish pronunciation and with some representative elements of Swedish culture.

VI.

\begin{tabular}{|l|c|}
\hline \multicolumn{1}{|c|}{ Course structure } & No. \\
hours
\end{tabular}

VII.

Syllabus outline

VII.1. Grammar 


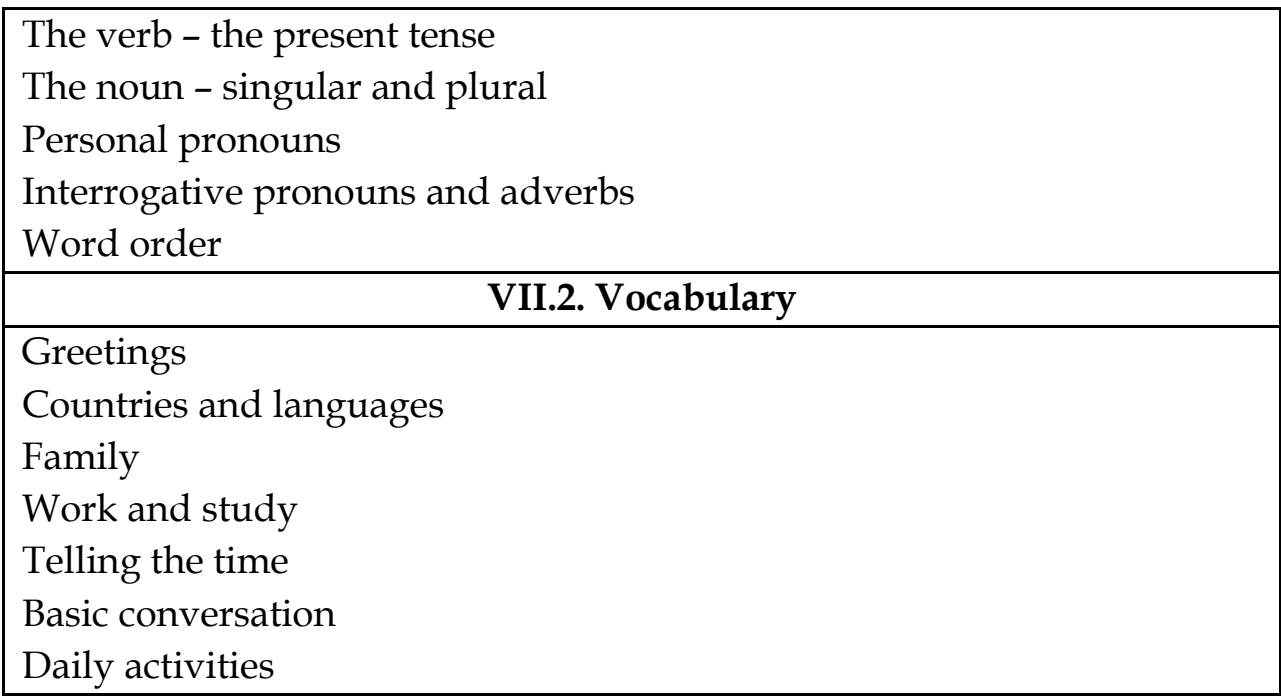

\section{VIII.}

\begin{tabular}{|c|c|}
\hline & References \\
\hline & $\begin{array}{l}\text { Scherrer, Paula \& Karl Lindemalm, Rivstart A1+A2 Textbok, } \\
\text { Stockholm: Natur och Kultur, } 2007\end{array}$ \\
\hline & $\begin{array}{l}\text { Scherrer, Paula \& Karl Lindemalm, Rivstart A1+A2 Övningsbok, } \\
\text { Stockholm: Natur och Kultur, } 2007\end{array}$ \\
\hline
\end{tabular}

IX.

\begin{tabular}{|c|c|}
\hline $\begin{array}{l}\text { Forms of } \\
\text { activity }\end{array}$ & $\begin{array}{l}\text { Methods and techniques used in the } \\
\text { teaching process }\end{array}$ \\
\hline Lecture & $\begin{array}{l}\text { Presentations, brainstorming, discussions, audio-video } \\
\text { materials }\end{array}$ \\
\hline Seminar & $\begin{array}{l}\text { Role-playing, exercises, listening comprehension, games, } \\
\text { story-telling etc. }\end{array}$ \\
\hline \multicolumn{2}{|l|}{ Application } \\
\hline Project & Movie making \\
\hline
\end{tabular}

$\mathrm{X}$.

\begin{tabular}{|l|l|l|}
\hline Type & $\begin{array}{l}\text { Assessment system (written, } \\
\text { written and oral, oral, others) }\end{array}$ & \\
\hline Exam & & \\
\hline Colloquium & & \\
\hline $\begin{array}{l}\text { Continuous } \\
\text { assessment }\end{array}$ & $\mathrm{X}$ & \\
\hline
\end{tabular}




\begin{tabular}{|l|l|l|}
\hline Project & $\mathrm{X}$ & \\
\hline
\end{tabular}

I.

\begin{tabular}{|c|c|c|c|c|}
\hline \multicolumn{2}{|c|}{ Course title } & \multicolumn{2}{|c|}{ FINNISH LANGUAGE } & \\
\hline \multicolumn{5}{|l|}{ II. } \\
\hline \multicolumn{5}{|c|}{$\begin{array}{c}\text { Course structure } \\
\text { (Number of hours per } \\
\text { summer school session) }\end{array}$} \\
\hline Level & Lecture & Seminar & $\begin{array}{c}\text { Practical } \\
\text { course }\end{array}$ & $\begin{array}{c}\text { Summer school } \\
\text { year }\end{array}$ \\
\hline A1 & 12 & 6 & & $1^{\text {st }}$ \\
\hline
\end{tabular}

III.

\begin{tabular}{|l|l|c|c|}
\hline $\begin{array}{l}\text { Optionality } \\
\text { category }\end{array}$ & Imposed & Optional & Freely chosen \\
\hline & & $\mathrm{X}$ & \\
\hline
\end{tabular}

IV.

\begin{tabular}{|l|l|l|l|l|}
\hline \multicolumn{5}{|c|}{ Supervisor } \\
\hline & \multicolumn{1}{|c|}{ Lecture } & \multicolumn{1}{|c|}{ Seminar } & Application & Project \\
\hline Name & Adél FURU & Adél FURU & & \\
\hline \multirow{3}{*}{ Institution } & Babeș-Bolyai & Babeș-Bolyai & & \\
& $\begin{array}{l}\text { University, } \\
\text { Cluj-Napoca }\end{array}$ & $\begin{array}{l}\text { University, } \\
\text { Cluj-Napoca }\end{array}$ & & \\
\hline Department & $\begin{array}{l}\text { Department of } \\
\text { Hungarian and } \\
\text { General }\end{array}$ & $\begin{array}{l}\text { Department of } \\
\text { Hungarian } \\
\text { and General } \\
\text { Linguistics }\end{array}$ & & \\
& Linguistics & Ph.D. student & & \\
\hline Scientific title & Ph.D. student & Phond & & \\
\hline Position & & & & \\
\hline
\end{tabular}

V.

\section{Objectives}

- learning the basics of the Finnish language (beginning with the alphabet);

- the students should: understand the message communicated orally; be able to convey a message correctly (phonetically and grammatically); be able to extract important information from a written text; be able to write a text respecting the spelling rules of the Finnish langauge.

VI. 


\begin{tabular}{|c|c|}
\hline Course structure & \multirow{2}{*}{$\begin{array}{l}\text { No. } \\
\text { hours }\end{array}$} \\
\hline VI.1. Lectures & \\
\hline Lecture 1: Hello and welcome! Hei ja tervetuloa! & 2 \\
\hline Lecture 2: The characters of the book. Kirjan henkilöt. & 2 \\
\hline Lecture 3: Exercises. Harjoitukset. & 2 \\
\hline Lecture 4: What nationality are you? Minkämaalainen sinä olet? & 2 \\
\hline Lecture 5: At the ice-cream stall. Jäätelökioskilla. & 2 \\
\hline Lecture 6: Finnish consonant gradation. K-p-t-vaihtelu. & 2 \\
\hline Total: & $\begin{array}{c}12 \\
\text { hours }\end{array}$ \\
\hline \multicolumn{2}{|l|}{ VI.2. Seminar } \\
\hline $\begin{array}{l}\text { Revision. Sumary. } \\
\text { Finnish puns: } \\
\text { balalaikka/dilileikka/hilihuikka/huliheikka. } \\
\text { Finnish songs. } \\
\text { Finnish children's books. } \\
\text { Total: }\end{array}$ & $\begin{array}{c}6 \\
\text { hours }\end{array}$ \\
\hline VI.3. Application (if the case) & \\
\hline $\begin{array}{l}\text { VI.4. Project topic (if the case) } \\
\end{array}$ & \\
\hline
\end{tabular}

VII.

\begin{tabular}{|l|}
\hline \multicolumn{1}{|c|}{ Syllabus outline } \\
\hline \multicolumn{1}{|c|}{ VII.1. Grammar } \\
\hline The verb to be. \\
Vowel harmony. \\
Conjugation of verbs, present simple, type 1. \\
Interrogative pronouns. \\
Interrogative particle. \\
Adverbs of place. \\
Genitive. \\
Possessive pronouns. \\
\hline \multicolumn{2}{|c|}{ VII.2. Vocabulary } \\
\hline The alphabet. \\
Greetings (formal, informal). \\
The days of the week. \\
Numerals.
\end{tabular}


Personal pronouns.

Countries, nationalities, languages.

The weather.

Shopping.

VIII.

\begin{tabular}{|l|l|}
\hline \multicolumn{1}{|c|}{ References } & \\
\hline Suomen mestari 1. & \\
\hline
\end{tabular}

IX.

\begin{tabular}{|l|l|}
\hline $\begin{array}{c}\text { Forms of } \\
\text { activity }\end{array}$ & \multicolumn{1}{c|}{$\begin{array}{c}\text { Methods and techniques used in the } \\
\text { teaching process }\end{array}$} \\
\hline Lecture & pair work activities; dialogue; listening activities (CD); \\
\hline Seminar & problem solving; class participation; recitation; \\
\hline Application & \\
\hline Project & \\
\hline
\end{tabular}

$\mathrm{X}$.

\begin{tabular}{|l|l|l|}
\hline Type & $\begin{array}{l}\text { Assessment system } \\
\text { (written, written and oral, } \\
\text { oral, others) }\end{array}$ & \\
\hline Exam & written & $\begin{array}{l}\text { - conjugation of verbs } \\
\text { (affirmative, negative); } \\
-\quad \text { RO-FI translation of } \\
\text { vocabulary; } \\
- \text { translation of cardinal } \\
\text { numbers; } \\
\text { - sentence formation }\end{array}$ \\
\hline Colloquium & & \\
\hline $\begin{array}{l}\text { Continuous } \\
\text { assessment }\end{array}$ & & \\
\hline Project & & \\
\hline
\end{tabular}

I.

\begin{tabular}{|l|l|}
\hline Course title & ESTONIAN LANGUAGE \\
\hline
\end{tabular}

II.

\section{Course structure}

(Number of hours per 


\begin{tabular}{|c|c|c|c|c|}
\hline \multicolumn{5}{|c|}{ summer school session) } \\
\hline Level & Lecture & Seminar & $\begin{array}{c}\text { Practical } \\
\text { course }\end{array}$ & $\begin{array}{c}\text { Summer school } \\
\text { year }\end{array}$ \\
\hline A1 & 7 & 11 & & $1^{\text {st }}$ \\
\hline
\end{tabular}

III.

\begin{tabular}{|l|l|c|c|}
\hline $\begin{array}{l}\text { Optionality } \\
\text { category }\end{array}$ & Imposed & Optional & Freely chosen \\
\hline & & $\mathrm{X}$ & \\
\hline
\end{tabular}

IV.

\begin{tabular}{|l|l|l|l|l|}
\hline \multicolumn{5}{|c|}{ Supervisor } \\
\hline Name & \multicolumn{1}{|c|}{ Lecture } & \multicolumn{1}{|c|}{ Seminar } & Application & Project \\
& $\begin{array}{l}\text { Mihaela } \\
\text { Moagher }\end{array}$ & $\begin{array}{l}\text { Mihaela } \\
\text { Moagher }\end{array}$ & & \\
\hline Institution & University of & University of \\
Tartu & Tartu & & \\
\hline Department & Philosophy & Philosophy & & \\
\hline Scientific title & MA student & MA student & & \\
\hline Position & & & & \\
\hline
\end{tabular}

V.

\section{Objectives}

To introduce Estonian language (vocabulary and grammar) to students.

VI.

\begin{tabular}{|l|c|}
\hline \multicolumn{1}{|c|}{ Course structure } & $\begin{array}{l}\text { No. } \\
\text { hours }\end{array}$ \\
\hline Lecture 1: Tere! Ma olen... - Hi! I am... & $\mathbf{1}$ \\
Lecture 2: Minu pere - My family & $\mathbf{1}$ \\
Lecture 3: Mulle meeldib numbrid ja värvid - I like... numbers & $\mathbf{1}$ \\
and colors & \\
Lecture 4: Söögid ja joogid - Food and beverages & $\mathbf{1}$ \\
Lecture 5: Mis kell on? Millal? - What is the time? When? & $\mathbf{1}$ \\
Lecture 6: Mul on... , sul on..., tal on.... - I have..., you have..., he / & $\mathbf{1}$ \\
she has... & $\mathbf{1}$ \\
Final evaluation & $\mathbf{7}$ \\
Total: & \\
\hline
\end{tabular}




\begin{tabular}{|l|c|}
\hline \multicolumn{1}{|c|}{ VI.2. Seminar } & hours \\
\hline 1. Tere! Ma olen... - Hi! I am... & 2 \\
2. Minu pere - My family & $\mathbf{2}$ \\
3: Mulle meeldib numbrid ja värvid - I like... numbers and colors & $\mathbf{2}$ \\
4. Söögid ja joogid - Food and beverages & 2 \\
5. Mis kell on? Millal? - What is the time? When? & $\mathbf{2}$ \\
6. Mul on..., sul on..., tal on.... - I have..., you have..., he / she has... & $\mathbf{1}$ \\
& $\mathbf{1 1}$ \\
Total: & hours \\
\hline \multicolumn{2}{|c|}{ VI.3. Application (if the case) } \\
\hline VI.4. Project topic (if the case) \\
\hline
\end{tabular}

VII.

\begin{tabular}{|l|}
\hline \multicolumn{1}{|c|}{ Syllabus outline } \\
\hline \multicolumn{1}{|c|}{ VII.1. Grammar } \\
\hline $\begin{array}{l}\text { Present tense; personal and possessive pronouns; Estonian language cases } \\
\text { and postpositions; -ma and }-d a \text { infinitive; to have construction }\end{array}$ \\
\hline \multicolumn{1}{|c|}{ VII.2. Vocabulary } \\
\hline $\begin{array}{l}\text { Greetings; names of different countries, cities and places within the city; } \\
\text { name of the family members and other relatives; numbers and colors; } \\
\text { names of food and beverages; days of the week, name of the year's } \\
\text { months, name of the seasons. }\end{array}$ \\
\hline
\end{tabular}

\section{VIII.}

\begin{tabular}{|l|l|}
\hline \multicolumn{1}{|c|}{ References } & \\
\hline Jänese, Katrin 2011. Eesti keele grammatika. Unpublished Course. \\
University of Tartu \\
Toomet, Piret 2011. Introduction to Estonian Language. Unpublished \\
Course. University Of Tartu
\end{tabular}

IX.

\begin{tabular}{|l|l|}
\hline $\begin{array}{c}\text { Forms of } \\
\text { activity }\end{array}$ & \multicolumn{1}{c|}{$\begin{array}{c}\text { Methods and techniques used in the } \\
\text { teaching process }\end{array}$} \\
\hline Lecture & Expository method, demonstration \\
\hline Seminar & Collaboration, teaching games, exercise-based learning \\
\hline Application & \\
\hline Project & \\
\hline
\end{tabular}


X.

\begin{tabular}{|l|l|l|}
\hline Type & $\begin{array}{l}\text { Assessment system (written, } \\
\text { written and oral, oral, others) }\end{array}$ & \\
\hline Exam & Written & \\
\hline Colloquium & & \\
\hline $\begin{array}{l}\text { Continuous } \\
\text { assessment }\end{array}$ & & \\
\hline Project & & \\
\hline
\end{tabular}

I.

\begin{tabular}{|l|l|l|}
\hline Course title & LATVIAN LANGUAGE & \\
\hline
\end{tabular}

II.

\begin{tabular}{|c|c|c|c|c|}
\hline \multicolumn{4}{|c|}{$\begin{array}{c}\text { Course structure } \\
\text { (Number of hours per } \\
\text { summer school session) }\end{array}$} \\
\hline Level & Lecture & Seminar & $\begin{array}{c}\text { Practical } \\
\text { course }\end{array}$ & $\begin{array}{c}\text { Summer school } \\
\text { year }\end{array}$ \\
\hline A1 & 18 & & & 1 st \\
\hline
\end{tabular}

III.

\begin{tabular}{|l|l|c|c|}
\hline $\begin{array}{l}\text { Optionality } \\
\text { category }\end{array}$ & Imposed & Optional & Freely chosen \\
\hline & & $\mathrm{X}$ & \\
\hline
\end{tabular}

IV.

\begin{tabular}{|l|l|l|l|l|}
\hline \multicolumn{5}{|c|}{ Supervisor } \\
\hline & \multicolumn{1}{|c|}{ Lecture } & \multicolumn{1}{c|}{ Seminar } & Application & Project \\
\hline Name & Indra Lapinska & $\begin{array}{l}\text { Indra } \\
\text { Lapinska }\end{array}$ & & \\
\hline \multirow{3}{*}{ Institution } & $\begin{array}{l}\text { Latvian } \\
\text { Language } \\
\text { Agency }\end{array}$ & $\begin{array}{l}\text { Latvian } \\
\text { Language } \\
\text { Agency }\end{array}$ & & \\
\hline Department & & & & \\
\hline Scientific title & & & & \\
\hline Position & & & & \\
\hline
\end{tabular}

V.

\section{Objectives}


The course is offered for students who would like to learn basics of Latvian and get acquainted with the phonetic, grammatical and semantic structure of the language. It is based on the communicative approach in Latvian as a foreign language teaching.

The aim of the course is

- to develop the ability to start using Latvian in everyday speech, to feel at ease in Latvian society as well as make contacts,

- to develop students socio-cultural competence to give short information about modern culture and customs.

The course is provided for beginners, based on thematic planning as well as on tasks that develop four skills - listening, reading, writing, and speaking. The main questions of Latvian grammar are trained in each lesson. It is a breakthrough course which provides the first steps into Latvian. The set target level is the A1.1 level according to the scale of language proficiency levels defined by the European Common Framework of Reference: Learning, Teaching, Assessment.

VI.

\begin{tabular}{|c|c|c|}
\hline \multicolumn{2}{|r|}{ Course structure } & \multirow{2}{*}{$\begin{array}{l}\text { No. } \\
\text { hours }\end{array}$} \\
\hline & VI.1. Lectures & \\
\hline Lecture 1 & $\begin{array}{l}\text { Me. } \\
\text { Es. }\end{array}$ & 2 \\
\hline Lecture 2 & $\begin{array}{l}\text { My country. } \\
\text { Mana valsts. }\end{array}$ & 2 \\
\hline Lecture 3 & $\begin{array}{l}\text { My nationality, my language. } \\
\text { Mana tautība, valoda. }\end{array}$ & 2 \\
\hline Lecture 4 & $\begin{array}{l}\text { My relatives. } \\
\text { Mani radinieki. }\end{array}$ & 2 \\
\hline Lecture 5 & $\begin{array}{l}\text { My family. } \\
\text { Mana ǵimene. }\end{array}$ & 2 \\
\hline Lecture 6 & $\begin{array}{l}\text { My town. } \\
\text { Mana pilsēta. }\end{array}$ & 2 \\
\hline Lecture 7 & $\begin{array}{l}\text { My address. My home. } \\
\text { Mana adrese. Mana māja. }\end{array}$ & 2 \\
\hline Lecture 8 & $\begin{array}{l}\text { My occupation. My work. } \\
\text { Mana nodarbošanās. Mans darbs. }\end{array}$ & 2 \\
\hline Lecture 9 & My time. & 2 \\
\hline
\end{tabular}




\begin{tabular}{|l|c|c|}
\hline & Mans laiks. Revision (Lecture 1-9). Test. & $\begin{array}{c}18 \\
\text { hours }\end{array}$ \\
\hline VI.2. Seminar & \\
\hline Total: & \\
\hline \multicolumn{2}{|c|}{ VI.3. Application (if the case) } & \\
\hline VI.4. Project topic (if the case) & \\
\hline
\end{tabular}

VII.

\begin{tabular}{|c|c|}
\hline \multicolumn{2}{|r|}{ Syllabus outline } \\
\hline \multicolumn{2}{|r|}{ VII.1. Grammar } \\
\hline Lecture 1 & $\begin{array}{l}\text { Latvian alphabet. Pronunciation and spelling. } \\
\text { Questions kas? kā? (who?/what?), yes/no-questions. } \\
\text { Personal pronouns (the Nominative and Accusative } \\
\text { case).The Nominative endings of nouns. Conjugation } \\
\text { of the irregular verb būt (to be), verb saukt, present } \\
\text { tense I k. Negative sentence. }\end{array}$ \\
\hline Lecture 2 & $\begin{array}{l}\text { Questions No kurienes jūs esat? (Where are you from?) } \\
\text { Kā jums klājas? (How are you?). Personal pronouns (the } \\
\text { Dative case).The Genitive endings of nouns. Latvian } \\
\text { alphabet. }\end{array}$ \\
\hline Lecture 3 & $\begin{array}{l}\text { Question Kāda valodā jūs runājat? (What language do } \\
\text { you speak?) } \\
\text { The Locative endings of nouns. Conjugation of the } \\
\text { verb runāt (to speak), present tense II k. }\end{array}$ \\
\hline Lecture 4 & $\begin{array}{l}\text { Possessive, demonstrative pronouns. The Locative } \\
\text { endings of nouns. } \\
\text { Agreement of pronoun and substantive endings. }\end{array}$ \\
\hline Lecture 5 & $\begin{array}{l}\text { Questions Kurt jūs dzīvojat? (Where do you live?) Kas } \\
\text { jūs esat? Ko jūs darāt? (What do you do?) Vai jūs esat ...? } \\
\text { (Are you ...?) Vai jums ir ...(Do you have ...?) .The } \\
\text { Locative endings of nouns. Conjugation of the verb } \\
\text { dzìvot, strādāt, studēt (to live, to work, to study) + the } \\
\text { Locative case, present tense II k. }\end{array}$ \\
\hline Lecture 6 & $\begin{array}{l}\text { Questions Cik liela? Cik veca? Cik daudz? (How big? } \\
\text { How old? How many/much?). The Locative endings } \\
\text { of nouns. Ordinal numerals. Agreement of noun and } \\
\text { adjective endings. }\end{array}$ \\
\hline
\end{tabular}




\begin{tabular}{|c|c|}
\hline Lecture 7 & $\begin{array}{l}\text { Question Käda ir jüsu adrese? (What is your address?) } \\
\text { The Dative and Accusative endings of nouns. } \\
\text { Communication on phone. Cardinal numerals. } \\
\text { The reflexive verb atrasties. Conjugation of the verbs } \\
\text { braukt, iet }+u z \text { (the Locative case), present tense I k. The } \\
\text { Genitive endings of noun. Agreement of noun and } \\
\text { adjective endings. Direct Object. The Accusative } \\
\text { endings of noun. Prepositions uz (on), pie (at), virs } \\
\text { (above), zem (under) + the Genitive case. Conjugation } \\
\text { of the verbs apciemot, dāvināt (to visit, to give a present), } \\
\text { present tense. The phrase man patik (I like). }\end{array}$ \\
\hline Lecture 8 & 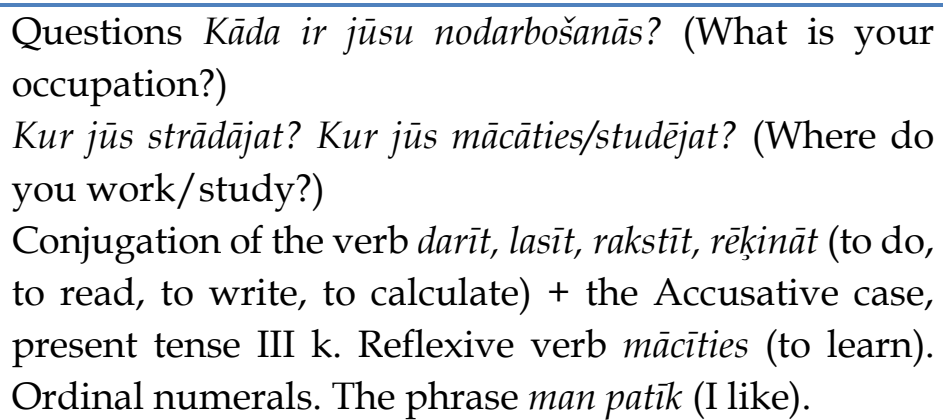 \\
\hline Lecture 9 & $\begin{array}{l}\text { Questions Kad jūs ejat uz darbu?(When do you go for } \\
\text { work?) Cik pulkstenis? Cikos? (What time is it? At what } \\
\text { time?). Conjugation of the verbs braukt, iet +uz (the Acc. } \\
\text { case), present tense I k. Conjugation of the verb plānot } \\
\text { (to plan) + the Acc. case, present tense II k. } \\
\text { Overview - Latvian noun and verb system. } \\
\text { Revision exercises. }\end{array}$ \\
\hline \multicolumn{2}{|r|}{ VII.2. Vocabulary } \\
\hline Lecture 1 & Lexis: greetings. Getting acquainted. \\
\hline Lecture 2 & Lexis: country names in Latvian. \\
\hline Lecture 3 & Lexis: languages, nationalities in Latvian. \\
\hline Lecture 4 & Lexis: family members, relatives. \\
\hline Lecture 5 & Lexis: place of living, occupation, civil status. \\
\hline Lecture 6 & Lexis: numerals, Latvia, Riga in numbers, city objects. \\
\hline Lecture 7 & $\begin{array}{l}\text { Lexis: address, talking on phone (phrases), } \\
\text { description of location; rooms, furniture }\end{array}$ \\
\hline
\end{tabular}




\begin{tabular}{|l|l|}
\hline Lecture 8 & $\begin{array}{l}\text { Lexis: occupations, description of an institution, } \\
\text { school, university }\end{array}$ \\
\hline Lecture 9 & $\begin{array}{l}\text { Lexis: days of the week, time } \\
\text { Revision of vocabulary learned }\end{array}$ \\
\hline
\end{tabular}

VIII.

\section{References}

During the course several materials will be used:

- The book for secondary school students Atvērsim vārtus!, LVA 2011

- The book Latvian for Foreign Students Latviešu valoda studentiem. Mācìbu lìdzeklis latviešu valodas kā svešvalodas apgūšanai. I. KlēvereVelhli, Nikola Naua, Rìga 2012

- The exercise book Palīgā 1, I.Budvike, Br.Šilinga, LVAVA 2009

- different internet sources, dictionaries.

IX.

\begin{tabular}{|l|l|}
\hline \multicolumn{1}{|c|}{$\begin{array}{c}\text { Forms of } \\
\text { activity }\end{array}$} & \multicolumn{1}{c|}{$\begin{array}{c}\text { Methods and techniques used in the } \\
\text { teaching process }\end{array}$} \\
\hline Lecture & Interactive tasks, group work, pair work shall be organized. \\
\hline Seminar & \\
\hline Application & \\
\hline Project & \\
\hline
\end{tabular}

$\mathrm{X}$.

\begin{tabular}{|l|l|l|}
\hline Type & $\begin{array}{l}\text { Assessment system (written, } \\
\text { written and oral, oral, others) }\end{array}$ & \\
\hline Exam & & \\
\hline Colloquium & & \\
\hline $\begin{array}{l}\text { Continuous } \\
\text { assessment }\end{array}$ & X, written test & \\
\hline Project & & \\
\hline
\end{tabular}

I.

\begin{tabular}{|l|l|l|}
\hline Course title & $\begin{array}{l}\text { CRASH COURSE OF LITHUANIAN } \\
\text { LANGUAGE AND CULTURE }\end{array}$ & \\
\hline
\end{tabular}

II.

\section{Course structure}

(Number of hours per 


\begin{tabular}{|c|c|c|c|c|}
\hline \multicolumn{5}{|c|}{ summer school session) } \\
\hline Level & Lecture & Seminar & $\begin{array}{c}\text { Practical } \\
\text { course }\end{array}$ & $\begin{array}{c}\text { Summer school } \\
\text { year }\end{array}$ \\
\hline A1 & 5 & & 13 & $1^{\text {st }}$ \\
\hline
\end{tabular}

III.

\begin{tabular}{|l|l|c|c|}
\hline $\begin{array}{l}\text { Optionality } \\
\text { category }\end{array}$ & Imposed & Optional & Freely chosen \\
\hline & & $\mathrm{X}$ & \\
\hline
\end{tabular}

IV.

\begin{tabular}{|l|l|l|l|l|}
\hline \multicolumn{2}{|c|}{ Lecture } & \multicolumn{1}{|c|}{ Seminar } & Application & $\begin{array}{c}\text { Projec } \\
\mathrm{t}\end{array}$ \\
\hline Name & Jūratè Derukaitè & $\begin{array}{l}\text { Jūratė } \\
\text { Derukaitè }\end{array}$ & & \\
\hline Institution & $\begin{array}{l}\text { Klaipèda } \\
\text { University }\end{array}$ & $\begin{array}{l}\text { Klaipèda } \\
\text { University }\end{array}$ & & \\
\hline Department & $\begin{array}{l}\text { Faculty of } \\
\text { Humanities, } \\
\text { Centre for } \\
\text { Languages and } \\
\text { Cultures }\end{array}$ & $\begin{array}{l}\text { Faculty of } \\
\text { Humanities, } \\
\text { Centre for } \\
\text { Languages } \\
\text { and Cultures }\end{array}$ & & \\
\hline Scientific title & MA & MA & & \\
\hline \multirow{5}{*}{ Position } & $\begin{array}{l}\text { Director of the } \\
\text { Centre for } \\
\text { Languages and } \\
\text { Cultures; } \\
\text { lecturer }\end{array}$ & $\begin{array}{l}\text { Director of the } \\
\text { Centre for } \\
\text { Languages } \\
\text { and Cultures; } \\
\text { lecturer }\end{array}$ & & \\
\hline
\end{tabular}

V.

\section{Objectives}

1. To give basic knowledge of Lithuanian language at beginners' level (short introductory course).

2. Along with the linguistic preparation, to acquaint students with the Lithuanians' national character, traditions, customs.

3. To provide with the basic cultural content (Lithuania in the past and nowadays).

VI. 


\begin{tabular}{|c|c|}
\hline Course structure & \multirow{2}{*}{$\begin{array}{l}\text { No. } \\
\text { hours }\end{array}$} \\
\hline VI.1. Lectures & \\
\hline $\begin{array}{l}\text { Lecture 1: Vocabulary: Meeting people. Main acquaintance and } \\
\text { presentation phrases. Lithuanian names and surnames. Names of } \\
\text { the countries. Grammar: Personal pronouns. Nouns: number, } \\
\text { gender, cases. Verb büti ('to be'). Introduction of nominative and } \\
\text { genitive cases. Culture: Lithuania. Lithuanian language. }\end{array}$ & 2 \\
\hline $\begin{array}{l}\text { Lecture 2: Vocabulary: Lithuanian names and surnames. Grammar: } \\
\text { Main survival verbs. Introduction into verbs tenses. Culture: } \\
\text { Famous people of Lithuania. }\end{array}$ & 2 \\
\hline $\begin{array}{l}\text { Lecture 3: Vocabulary: Numerals. Cardinal numerals. Telling the } \\
\text { age. Money. Grammar: Numerals with nouns. Culture: Lithuanian } \\
\text { currency. }\end{array}$ & 2 \\
\hline $\begin{array}{l}\text { Lecture 4: Vocabulary: Getting around in town. Grammar: } \\
\text { prepositions of direction and place. Culture: Vilnius, the capital } \\
\text { of Lithuania }\end{array}$ & 2 \\
\hline $\begin{array}{l}\text { Lecture 5: Vocabulary: Telling the date and time. Grammar: } \\
\text { Interrogatives. Culture: National festive days. }\end{array}$ & 3 \\
\hline $\begin{array}{l}\text { Lecture 6: Vocabulary: Food. Grammar: practising singular and } \\
\text { plural forms of nouns. Culture: Lithuanian national cuisine }\end{array}$ & 3 \\
\hline $\begin{array}{l}\text { Lecture 7: Vocabulary: Describing people and things. Grammar: } \\
\text { practising adjectives with nouns. Culture: Places and things of } \\
\text { interest in Lithuania }\end{array}$ & 2 \\
\hline $\begin{array}{l}\text { Lecture 8: Ethnographical regions of Lithuania. Curious things } \\
\text { about Lithuanian dialects. Singing Lithuanian folk songs. The }\end{array}$ & 2 \\
\hline $\begin{array}{l}\text { evaluation of the course. } \\
\text { Total: }\end{array}$ & 18 \\
\hline VI.2. Seminar & \\
\hline VI.3. Application (if the case) & \\
\hline VI.4. Project topic (if the case) & \\
\hline
\end{tabular}

VII.

\begin{tabular}{|l|}
\hline \multicolumn{1}{|c|}{ Syllabus outline } \\
\hline VII.1. Grammar \\
\hline $\begin{array}{l}\text { Phonetical system. Basic knowledge of the grammatical system: nouns, } \\
\text { verbs, numbers, adjectives, pronouns, prepositions. Afirmative and } \\
\text { negative sentences. Interrogatives. Peculiarities of the syntactical system. }\end{array}$ \\
\hline
\end{tabular}




\section{VII.2. Vocabulary}

Meeting people. Main acquaintance and presentation phrases. Lithuanian names and surnames. Names of the countries.

Numerals. Cardinal numerals. Telling the age. Money.

Getting around in town.

Telling the date and time.

Food.

Describing people and things.

\section{VIII.}

\begin{tabular}{|l|l|}
\hline \multicolumn{1}{|c|}{ References } & \\
\hline Stumbrienė V., Kaškelevičienè A. Nė dienos be lietuvių kalbos. Vilniu \\
Gimtasis žodis, 2011. \\
Jurgaitytė V., Derukaitè J. LABAS: Klaipėdos universitetas, 2013 \\
http://www.oneness.vu.lt/lt/ \\
http://www.online.lt/ \\
http://www.surfacelanguages.com/language/Lithuanian \\
Other related websites
\end{tabular}

IX.

\begin{tabular}{|l|l|}
\hline \multicolumn{1}{|c|}{$\begin{array}{c}\text { Forms of } \\
\text { activity }\end{array}$} & \multicolumn{1}{|c|}{$\begin{array}{c}\text { Methods and techniques used in the } \\
\text { teaching process }\end{array}$} \\
\hline Lecture & $\begin{array}{l}\text { Activities and techniques typical for the Communicative } \\
\text { Approach }\end{array}$ \\
\hline Seminar & \\
\hline Application & \\
\hline Project & \\
\hline
\end{tabular}

$\mathrm{X}$.

\begin{tabular}{|l|l|l|}
\hline Type & $\begin{array}{l}\text { Assessment system (written, } \\
\text { written and oral, oral, others) }\end{array}$ & \\
\hline Exam & Written and oral & \\
\hline Colloquium & & \\
\hline $\begin{array}{l}\text { Continuous } \\
\text { assessment }\end{array}$ & Written and oral & \\
\hline Project & & \\
\hline
\end{tabular}

I. 


\begin{tabular}{|l|l|}
\hline Course title & $\begin{array}{l}\text { THE NORWEGIAN CONSTITUTION AT } 200 \\
\text { YEARS }\end{array}$ \\
\hline
\end{tabular}

II.

\begin{tabular}{|c|c|c|c|c|}
\hline \multicolumn{4}{|c|}{$\begin{array}{c}\text { Course structure } \\
\text { (Number of hours per } \\
\text { summer school session) }\end{array}$} \\
\hline Level & Lecture & Seminar & $\begin{array}{c}\text { Practical } \\
\text { course }\end{array}$ & $\begin{array}{c}\text { Summer school } \\
\text { year }\end{array}$ \\
\hline Beginners & 12 & & & $1^{\text {st }}$ \\
\hline
\end{tabular}

III.

\begin{tabular}{|l|l|c|c|}
\hline $\begin{array}{l}\text { Optionality } \\
\text { category }\end{array}$ & Imposed & Optional & Freely chosen \\
\hline & & $\mathbf{X}$ & \\
\hline
\end{tabular}

IV.

\begin{tabular}{|l|l|l|l|l|}
\hline \multicolumn{5}{|c|}{ Supervisor } \\
\hline & \multicolumn{1}{|c|}{ Lecture } & \multicolumn{1}{|c|}{ Seminar } & Application & Project \\
\hline Name & Ola Mestad & Ola Mestad & & \\
\hline Institution & $\begin{array}{l}\text { University of } \\
\text { Oslo }\end{array}$ & $\begin{array}{l}\text { University of } \\
\text { Oslo }\end{array}$ & & \\
\hline Department & Faculty of Law & $\begin{array}{l}\text { Faculty of } \\
\text { Law }\end{array}$ & & \\
\hline Scientific title & Ph.D. & Ph.D. & & \\
\hline Position & Professor & Professor & & \\
\hline
\end{tabular}

V.

\section{Objectives}

The course aims to make students learn how the Constitution was adopted in Norway in 1814 and how it developed throughout 200 years.

VI.

\begin{tabular}{|c|c|}
\hline Course structure & \multirow{2}{*}{$\begin{array}{l}\text { No. } \\
\text { hours }\end{array}$} \\
\hline VI.1. Lectures & \\
\hline Lecture 1: 1814 - A year of miracles for Norwegians? & 2 \\
\hline Lecture 2: The Constitution making process and content & 2 \\
\hline $\begin{array}{l}\text { Lecture 3: Constitutional survival of war and union with Sweden } \\
\text { 1814-1905 }\end{array}$ & 2 \\
\hline Lecture 4: Constitutional transformations & 2 \\
\hline Lecture 5: EEA - Norway's relationship with the European Union & 2 \\
\hline
\end{tabular}




\begin{tabular}{|c|c|}
\hline $\begin{array}{l}\text { Lecture 6: Modernization of human rights protection in the } \\
\text { Constitution in } 2014 \\
\text { Total: }\end{array}$ & $\begin{array}{c}2 \\
12 \\
\text { hours }\end{array}$ \\
\hline VI.2. Seminar & \\
\hline VI.3. Application (if the case) & \\
\hline VI.4. Project topic (if the case) & \\
\hline
\end{tabular}

VII.

\section{Syllabus outline}

Lecture 1: 1814 - A year of miracles for Norwegians?

- Nordic aspects of the Napoleonic wars

- The treaty of Kiel and its effects

Lecture 2: The Constitution making process and content

- How to make a constitution

- Popular sovereignty, separation of powers - freedom and equlity

Lecture 3: Constitutional survival of war and union with Sweden 18141905

- Great power politics - the Congress of Vienna

- Independence within a union

Lecture 4: Constitutional transformations

- Development of parliamentarian government (1884)

- Judicial review by the courts

Lecture 5: EEA - Norway's relationship with the European Union

- EEA Agreement 1992 - Integration without membership

- Development under the EEA Agreement

Lecture 6: Modernization of human rights protection in the Constitution in 2014

- Impact of the European Convention of Human Rights in Norway

- 2014 inclusion of several human rights in the Constitution

VIII.

\begin{tabular}{|c|c|}
\hline References & \\
\hline Mestad, Ola (2014). “Amerikansk inspirasjon i den norske grunnlova. \\
Frihetstreet i Nord-Amerikas jord. American inspiration in the \\
Norwegian Constitution. The tree of freedom on North American \\
soil”, in Gudleiv Forr (red.), Rødt, hvitt og blått. Norsk grunnlov, \\
amerikansk inspirasjon. ART PRO Forlag AS. Kapittel. 73 - 85 \\
Mestad, Ola (2014). “Korleis forske på grunnlova?”. Nytt Norsk Tidsskrift \\
\hline
\end{tabular}


(1). 53- 56

Mestad, Ola (2014). "Suvereniteten tilbakegitt det norske folk ved

Kieltraktaten. Det oversedde natur- og statsrettsgrunnlaget for norsk sjølvstende og grunnlov i 1814". Historisk tidsskrift (1). 3565

Mestad, Ola (2012). “Moderat revolusjonsgrunnlov". Klassekampen. May 16,2012

Mestad, Ola (2008). “Næringsfridom i 1814grunnlova", in Forfatningsteori møter 1814. Akademisk Publisering. 21-94

IX.

\begin{tabular}{|l|l|}
\hline $\begin{array}{c}\text { Forms of } \\
\text { activity }\end{array}$ & \multicolumn{1}{c|}{$\begin{array}{c}\text { Methods and techniques used in the } \\
\text { teaching process }\end{array}$} \\
\hline Lecture & Thematic lectures, PowerPoint presentations, discussions \\
\hline Seminar & \\
\hline Application & \\
\hline Project & \\
\hline
\end{tabular}

$\mathrm{X}$.

\begin{tabular}{|l|l|l|}
\hline Type & $\begin{array}{l}\text { Assessment system (written, } \\
\text { written and oral, oral, others) }\end{array}$ & \\
\hline Exam & & \\
\hline Colloquium & & \\
\hline $\begin{array}{l}\text { Continuous } \\
\text { assessment }\end{array}$ & $\begin{array}{l}\text { Continuous assessment, oral } \\
\text { examination }\end{array}$ & \\
\hline Project & & \\
\hline
\end{tabular}

I.

\begin{tabular}{|l|l|}
\hline Course title & $\begin{array}{l}\text { A NORWEGIAN BUSINESS GAME AND THE } \\
\text { CURRENT STATE OF THE NORWEGIAN } \\
\text { ECONOMY }\end{array}$ \\
\hline
\end{tabular}

II.

\begin{tabular}{|c|c|c|c|}
\hline \multicolumn{4}{|c|}{$\begin{array}{c}\text { Course structure } \\
\text { (Number of hours per } \\
\text { summer school session) }\end{array}$} \\
\hline Level & Lecture & Seminar & Practical \\
\hline
\end{tabular}




\begin{tabular}{|c|c|c|c|c|}
\hline & & & course & year \\
\hline Beginners & 12 & 6 & & $1^{\text {st }}$ \\
\hline
\end{tabular}

III.

\begin{tabular}{|l|l|c|c|}
\hline $\begin{array}{l}\text { Optionality } \\
\text { category }\end{array}$ & Imposed & Optional & Freely chosen \\
\hline & & $\mathbf{X}$ & \\
\hline
\end{tabular}

IV.

\begin{tabular}{|c|c|c|c|c|}
\hline \multicolumn{5}{|c|}{ Supervisor } \\
\hline & Lecture & Seminar & Application & Project \\
\hline Name & Arne Dag Sti & Arne Dag Sti & & \\
\hline Institution & $\begin{array}{l}\text { University of } \\
\text { Agder } \\
\text { (retired) }\end{array}$ & $\begin{array}{l}\text { University of } \\
\text { Agder } \\
\text { (retired) }\end{array}$ & & \\
\hline Department & $\begin{array}{l}\text { Department of } \\
\text { Economics and } \\
\text { Finance }\end{array}$ & $\begin{array}{l}\text { Department of } \\
\text { Economics and } \\
\text { Finance }\end{array}$ & & \\
\hline Scientific title & $\begin{array}{l}\text { Ph.D. (Lic. } \\
\text { NHH) }\end{array}$ & $\begin{array}{l}\text { Ph.D. (Lic. } \\
\text { NHH) }\end{array}$ & & \\
\hline Position & Professor & Professor & & \\
\hline
\end{tabular}

V.

\section{Objectives}

To learn basic understanding of business concepts and the macroeconomics effects of business decisions and policies in modern economics, with special reference to the current state of the Norwegian economy.

VI.

\begin{tabular}{|l|c|}
\hline \multicolumn{1}{|c|}{ Course structure } & $\begin{array}{l}\text { No. } \\
\text { hours }\end{array}$ \\
\hline Lecture 1: Presentures & 2 \\
Reports & 2 \\
Lecture 2: Basic Marketing Decisions and their effects & 2 \\
Lecture 3: Basic Logistic Decisions and Cordination & 2 \\
Lecture 4: Basic Financial Decisions & 2 \\
Lecture 5: Macroeconomics & 2 \\
Lecture 6: Current Norwegian Dilemmaes in Economic Policies. & \\
Is it possible to upheld full employment and economic growth? & \\
\hline
\end{tabular}




\begin{tabular}{|l|c|}
\hline Total: & $\begin{array}{c}12 \\
\text { hours }\end{array}$ \\
\hline \multicolumn{1}{|c|}{ VI.2. Seminar } & \\
\hline $\begin{array}{l}\text { The seminar will be a mix of group discussions and business } \\
\text { decision taking, with tutoring from the supervisor. }\end{array}$ & \\
Total: & 6 \\
\hline \multicolumn{2}{|c|}{ hI.3. Application (if the case) } \\
\hline VI.4. Project topic (if the case) & \\
\hline
\end{tabular}

VII.

\section{Syllabus outline}

\section{VII.1. A Norwegian business game}

Arne Dag Sti: Økonomisk Bedriftsledelse (Business Management). Bedriftsøkonomisk Forlag AS, Oslo. 6. Opplag 2013.

Essential content will be translated to English and handed out in the lectures.

\section{VII.2. The current state of the Norwegian economy}

Macroeconomics: Paul A Samuelson: Economics, 1980 or later.

Bank of Norway: Last Report on financial stability July 2014.

Essential content will be handed out in lectures.

\section{VIII.}

\begin{tabular}{|l|l|}
\hline \multicolumn{3}{|c|}{ References } & \\
\hline Samuelson, Paul A. Economics. 1980 or later. \\
Sti, Arne Dag. Økonomisk Bedriftsledelse (Business Management). \\
Bedriftsøkonomisk Forlag AS, Oslo. 6. Opplag 2013. \\
Bank of Norway. Last Report on financial stability July 2014. \\
\hline
\end{tabular}

IX.

\begin{tabular}{|l|l|}
\hline \multicolumn{1}{|c|}{$\begin{array}{c}\text { Forms of } \\
\text { activity }\end{array}$} & \multicolumn{1}{c|}{$\begin{array}{c}\text { Methods and techniques used in the } \\
\text { teaching process }\end{array}$} \\
\hline Lecture & Traditional lectures 12 hours \\
\hline Seminar & $\begin{array}{l}\text { Decision training in groups 6 hours, under assistance from } \\
\text { the lecturer }\end{array}$ \\
\hline Application & \multicolumn{2}{|c|}{} \\
\hline Project & \\
\hline
\end{tabular}

$\mathbf{X}$. 


\begin{tabular}{|l|l|l|}
\hline Type & $\begin{array}{l}\text { Assessment system (written, } \\
\text { written and oral, oral, others) }\end{array}$ & \\
\hline Exam & & \\
\hline Colloquium & & Written \\
\hline $\begin{array}{l}\text { Continuous } \\
\text { assessment }\end{array}$ & $\begin{array}{l}\text { Quality of group decisions can be } \\
\text { graded, with a minimum level of } \\
\text { performance for acceptance }\end{array}$ & \\
\hline Project & & \\
\hline
\end{tabular}

I.

\section{\begin{tabular}{|l|l}
\hline Course title & THE VIKINGS \\
\hline
\end{tabular}}

II.

\begin{tabular}{|c|c|c|c|c|}
\hline \multicolumn{5}{|c|}{$\begin{array}{c}\text { Course structure } \\
\text { (Number of hours per } \\
\text { summer school session) }\end{array}$} \\
\hline Level & Lecture & Seminar & $\begin{array}{c}\text { Practical } \\
\text { course }\end{array}$ & $\begin{array}{c}\text { Summer school } \\
\text { year }\end{array}$ \\
\hline Beginners & 12 & - & - & 1 st \\
\hline
\end{tabular}

\section{III.}

\begin{tabular}{|l|l|c|c|}
\hline $\begin{array}{l}\text { Optionality } \\
\text { category }\end{array}$ & Imposed & Optional & Freely chosen \\
\hline & & $\mathrm{X}$ & \\
\hline
\end{tabular}

IV.

\begin{tabular}{|c|c|c|c|c|}
\hline \multicolumn{5}{|c|}{ Supervisor } \\
\hline & Lecture & Seminar & $\begin{array}{c}\text { Applic } \\
\text { ation }\end{array}$ & Project \\
\hline Name & Costel Coroban & Costel Coroban & & \\
\hline Institution & $\begin{array}{l}\text { Valahia Univ. } \\
\text { Tirgoviste/ } \\
\text { Ovidius Univ. of } \\
\text { Constanta }\end{array}$ & $\begin{array}{l}\text { Valahia Univ. } \\
\text { Tirgoviste/ } \\
\text { Ovidius Univ. of } \\
\text { Constanta }\end{array}$ & & \\
\hline Department & $\begin{array}{l}\text { Dept. of } \\
\text { History/Doctora } \\
1 \text { School of } \\
\text { Humanities }\end{array}$ & $\begin{array}{l}\text { Dept. of } \\
\text { History/Doctoral } \\
\text { School of } \\
\text { Humanities }\end{array}$ & & \\
\hline Scientific & Associate & Associate & & \\
\hline
\end{tabular}




\begin{tabular}{|l|l|l|l|l|}
\hline title & $\begin{array}{l}\text { researcher/PhD } \\
\text { Student }\end{array}$ & $\begin{array}{l}\text { researcher/PhD } \\
\text { Student }\end{array}$ & & \\
\hline \multirow{3}{*}{ Position } & $\begin{array}{l}\text { Associate } \\
\text { researcher/PhD } \\
\text { Student }\end{array}$ & $\begin{array}{l}\text { Associate } \\
\text { researcher/PhD } \\
\text { Student }\end{array}$ & & \\
& & & \\
\hline
\end{tabular}

V.

\section{Objectives}

- To be able to explain and infer information from historical sources belonging to the Viking civilization;

- To know and correctly apply historical and linguistic information from the age of the Viking expansion (cVII-XI A.D.);

- To manifest a positive and responsible attitude towards the complexity of the phenomenon that is called "the Viking invasions";

- To ascertain, understand and employ the critical viewpoints and theories regarding the mythological and religious aspect of Viking spirituality;

- To optimally and creatively capitalize one's own admiration for the Viking civilization.

VI.

\begin{tabular}{|l|l|}
\hline \multicolumn{1}{|c|}{ Course structure } & $\begin{array}{l}\text { No. } \\
\text { hours }\end{array}$ \\
\hline \multicolumn{1}{|c|}{ Lecture 1: Introduction. The Origins of the Vikings and their } & \\
Society. & \\
Lecture 2: Viking Art. Runes. & \\
Lecture 3: Viking women. & \\
Lecture 4: Religion and Mythology. Rituals, feasts and sacrifices. & \\
Lecture 5: Skaldic literature, Saga/sögur. & $\mathbf{1 2}$ \\
Lecture 6: Weapons and warships. The first invasions. & hours \\
Lecture 7: The Vikings in the Orkneys, Ireland and Scotland. & \\
Lecture 8: Medieval Viking Iceland. & \\
Lecture 9: The Vikings in Greenland, Vinland and Rus. \\
Lecture 10: The Vikings and Alfred the Great's England. Viking \\
Normandy. & \\
Lecture 11: Scandinavian England. The Bayeux tapestry. & \\
Lecture 12: The Vikings and Early Christianity. Final evaluation. & \\
Total: 12 & \\
\hline
\end{tabular}




\begin{tabular}{|c|c|}
\hline VI.2. Seminar & \\
\hline VI.3. Application (if the case) & \\
\hline VI.4. Project topic (if the case) & \\
\hline
\end{tabular}

VII.

\section{Syllabus outline}

Lecture 1: Introduction. The Origins of the Vikings and their Society -Locating the Old Norse people; the ethimology of the word "viking";

-The origins of the Viking society;

-The Old Norse community, social classes, Rígspula: Jarl, Karl, Thrall;

-The military classes: Hird, Bondi/Bondar, Vik; Berserker;

-Old Norse Law: Thing, Allthing, exile, wergeld, the Runic law;

-Egil's Saga, feudal relations, marriage, the importance of good fortune, the royal court.

Lecture 2: Viking Art. Runes.

-Pre-viking ornaments, animal symbols;

-ritual masks, motifs, the Borre style, jewelry, the Mammen style;

-the Urnes style, mysterious animal symbols;

--the Runic alphabet, reading, writing, well-known inscriptions, interpretation of runic texts.

\section{Lecture 3: Viking women.}

-the role of women and their social position in the Viking society;

-women in Saga/sögur;

-weddings, fidelity, divorce, children and childhood, royal succession;

-sports and games, celebrations, traditions, cooking, holiday recipes, textiles;

-women explorers.

Lecture 4: Religion and Mythology. Rituals, feasts and sacrifices. -the Edda, Voluspa, Heimskringla;

-Cosmology: Ginnungagap, Audumbla, Ygdrassil, Ymir, Buri and Bor, Bestla, gods and giants, Ask and Embla;

-the Pantheon, Odin, Vili and Ve, the artefacts of the gods, Frey and Freyja, Heimdall, Loki, Thor, Baldr, Tyr, Hel;

-Midgard, Asgard, Valhalla, Nifleheim, Ragnarök; 
-The Walkyries, Elves and other spirits, dwarves, gnomes, dragons, trolls, monsters, Beowulf;

-Rituals, celebrations, sacrifices, the cult.

Lecture 5: Skaldic literature, Saga/sögur.

- Söguöld.

-classification of sögur, motifs, locations, images, scenes;

-Egils Saga, Volsungasaga, Heimskringla, Eirik's Saga, Vinland Saga; -the Skalds, Icelandic sögur.

Lecture 6: Weapons and warships. The first invasions.

-Viking warships, Hjortspring ship, the Sutton Hoo ship, naval techonology, the Oseberg ship;

-Knarr and other types of vessels, navigation instruments;

-metalsmiths and weaponsmithing;

-types of weapons, axes, breidox, swords, spears;

-archery, shields, armour, war steeds, coifs;

-types of raids, battles, strandhogg;

-causes of Viking expansion, the first invasions on the European mainland.

Lecture 7: The Vikings in the Orkneys, Ireland and Scotland.

-Orkneyinga Saga, the invasion in the North Islands and Caithness;

-Haraldr Harfragi, Earl Rognvald of Møre, Rognvald Eysteinsson, Sigurd the Brave, Olav Tryggvasson;

-the Viking kingdom of Dublin, Longphort, the Battle of Clontarf;

-Laithlind; Soxulfr, Turges, Haakon, the Kingdom of Strathclyde;

Lecture 8: Medieval Viking Iceland.

-historical sources;

-Erik the Red's Saga (Eiríks saga rauða); Íslendingabók;

-the medieval Icelandic civilization (864-1350), ",the Icelandic miracle".

Lecture 9: The Vikings in Greenland, Vinland and Rus.

- Íslendingabók, Eiríks saga rauða; The Primary Chronicle (Povest Vremmenîkh Let);

-the first expeditions, Gunnbjörn Ulfsson;

-the colonization of Greenland; 
-Vinland, the L'Anse aux Meadows settlement, Helluland, Markland;

-Rus, Rurik, the foundation of Novgorod, the first contacts with the Arabs, Slavs; the Varangians.

Lecture 10: The Vikings and Alfred the Great's England. Viking Normandy.

-the Anglo-Saxon Chronicle, De moribus et actis primorum Normannorum ducum.

-the conquest of England; the invasion of Guthrum's Danes.

-Alfred the Great's resistance against the Vikings, the defeat of Guthrum, Ethaldun battle, Alfred's reforms, the treaty between Alfred and Guthrun, Danelaw;

-Rollo (Hrolf the Ganger), Gesta Danorum, the foundation of Normandy, the Treaty of Saint-Claire-sur-Epte, Normandy to William the Bastard.

Lecture 11: Scandinavian England. The Bayeux tapestry.

-Gesta Normanorum Ducum, the Bayeux Tapestry;

-Harald Hardrada, Knut the Great, Harthacnut, Edward the Confessor, Harald II Godwinson;

-the battles of Fulford, Stamford Bridge, Hastings 1066, the invasion of William the Conqueror; Domesday Booke, the conquest of England and its legacy.

Lecture 12: The Vikings and Early Christianity. Final evaluation. -early Christian missionaries in Scandinavia;

-Denmark: Harald Bluetooth, relations with the Carolingian Empire and the Holy Roman Empire, Valdemar the Great, Bishop Absalon, Valdemar II.

-Sweden: the monk Ansgar and the missionaries; the Yngling kings, Erik the Victorious, King Olof Skötkonung, Erik the Holy (Saint Eric).

-Norway: King Harald Harfragi, the missionary kings Olav Tryggvasson, Saint Olav, Haakon the Good.

-Final evaluation.

VIII.

\begin{tabular}{|c|c|}
\hline References & \\
\hline & \\
\hline
\end{tabular}


Beowulf, translation by Dan Duțescu şi Leon Levițchi, Editura pentru Literatură Universală, Bucureşti, 1969.

Cântecul nibelungilor. Editura de Stat pentru Literatură şi Artă: Bucureşti, 1958. Verse adaptation by Adrian Maniu.

Cântecul Nibelungilor. Saeculum: Bucharest, 2008. Translation by Claudiu Paradais.

Edda. Bucureşti: Saeculum I.O., 2005. Translation by Magda Petculescu, Foreword by Dan Grigorescu.

Egils Saga. London: Viking Society for Northern Research, 2003. Edited by Bjarni Einarsson.

The Poetic Edda. Two Volumes in One. Princeton University Press:

Princeton, 1936. Translated with Introduction and Notes by Henry Adams Bellows.

Walhalla şi Thule. Mituri şi legende vechi germanice. Vol. 1, 2. Editura Minerva: Bucureşti, 1977. Readaptation by Mihai Isbăşescu.

Baedeker, Karl. Civilizația germanică şi a vikingilor. Prietenii Cărții: Bucureşti, 2006. Translation by Liana Gomboşiu.

Belcin, Cornelia. Popescu, Alexandru. Vikingii. Albatros: Bucureşti, 1976. Bengtsson, Frans G. Vikingii. O povestire istorică din vremurile străbune. Dacia: Cluj, 1974. Translation by Constantin A. Gâdei.

Boyer, Régis. Islanda medievală. Vikingii. ALL: Bucureşti, 2002.

Durand, Frédéric. Vikingii. Corint: Bucureşti, 2003. Translation by Ovidiu Cristea.

Hollander, Lee M. Old Norse Poems. London: Abela Publishing, 2010. Jinga, Cristina. Comorile Nibelungilor. Prietenii Cărții: Bucureşti, 2003. Logan, F. Donald, Vikingii în istorie. Editura Bălcescu: Bucureşti, 1990. Translation by Mariana Grancea.

Lorint, Florica. Oamenii nordului. Editura Ştiințifică: Bucureşti, 1965. Morogan, Elena-Maria. Mitologia Nordică. Mituri şi legende. Editura Enciclopedică: Bucureşti, 1992.

Sawyer, Peter, The Oxford Illustrated History of the Vikings, Oxford, OUP, 2001.

Sturlson, Snorri. Heimskringla or the Chronicles of the Kings of Norway. 1996. Edited, proofed, and prepared by Douglas B. Killings.

\section{On-line sources:}

The poetic Edda in Old Norse and English, http:/ / www.voluspa.org/. 


\begin{tabular}{|cc|}
\hline Scandinavian & Runic-text \\
http:// www.nordiska.uu.se/forskn/samnord.htm. & Base, \\
The Vikings, on-line course by Professor Dr. Sally Vaughn, University of \\
Houston, https:// www.youtube.com/watch?v=GN89xSq9tdo
\end{tabular}

IX.

\begin{tabular}{|l|l|}
\hline \multicolumn{1}{|c|}{$\begin{array}{c}\text { Forms of } \\
\text { activity }\end{array}$} & \multicolumn{1}{|c|}{$\begin{array}{c}\text { Methods and techniques used in the } \\
\text { teaching process }\end{array}$} \\
\hline Lecture & $\begin{array}{l}\text { Lecturing, expository, discovery, brainstorming, mind } \\
\text { mapping. }\end{array}$ \\
\hline Seminar & - \\
\hline Application & - \\
\hline Project & - \\
\hline
\end{tabular}

$X$.

\begin{tabular}{|l|l|l|}
\hline Type & $\begin{array}{l}\text { Assessment system (written, } \\
\text { written and oral, oral, others) }\end{array}$ & \\
\hline Exam & written & \\
\hline Colloquium & - & \\
\hline $\begin{array}{l}\text { Continuous } \\
\text { assessment }\end{array}$ & oral & \\
\hline Project & - & \\
\hline
\end{tabular}

I.

\begin{tabular}{|l|l|}
\hline Course title & $\begin{array}{l}\text { HENRIK IBSEN - CONTEMPORARY } \\
\text { PERSPECTIVES }\end{array}$ \\
\hline
\end{tabular}

II.

\begin{tabular}{|c|c|c|c|c|}
\hline \multicolumn{5}{|c|}{$\begin{array}{c}\text { Course structure } \\
\text { (Number of hours per } \\
\text { summer school session) }\end{array}$} \\
\hline Level & Lecture & Seminar & $\begin{array}{c}\text { Practical } \\
\text { course }\end{array}$ & $\begin{array}{c}\text { Summer school } \\
\text { year }\end{array}$ \\
\hline Beginners & 6 & 6 & & $1^{\text {st }}$ \\
\hline
\end{tabular}

III.

\begin{tabular}{|l|l|c|c|}
\hline $\begin{array}{l}\text { Optionality } \\
\text { category }\end{array}$ & Imposed & Optional & Freely chosen \\
\hline & & $\mathrm{X}$ & \\
\hline
\end{tabular}


IV.

\begin{tabular}{|l|l|l|l|l|}
\hline \multicolumn{5}{|c|}{ Supervisor } \\
\hline Name & \multicolumn{1}{|c|}{ Lecture } & \multicolumn{1}{c|}{ Seminar } & Application & Project \\
\hline Institution & $\begin{array}{l}\text { Alexandru Ioan } \\
\text { Cuza University } \\
\text { of Iaşi }\end{array}$ & $\begin{array}{l}\text { Crina Leon } \\
\text { Alexandru Ioan } \\
\text { Cuza University } \\
\text { of Iaşi }\end{array}$ & & \\
\hline Department & $\begin{array}{l}\text { Faculty of } \\
\text { Letters }\end{array}$ & $\begin{array}{l}\text { Faculty of } \\
\text { Letters }\end{array}$ & & \\
\hline $\begin{array}{l}\text { Scientific } \\
\text { title }\end{array}$ & Ph.D. & Ph.D. & & \\
\hline Position & $\begin{array}{l}\text { Scientific } \\
\text { researcher } \\
\text { Teacher of } \\
\text { Norwegian }\end{array}$ & $\begin{array}{l}\text { Scientific } \\
\text { researcher } \\
\text { Teacher of } \\
\text { Norwegian }\end{array}$ & & \\
\hline
\end{tabular}

V.

\section{Objectives}

The course aims to make students acquainted with the life and work of the Norwegian writer Henrik Ibsen, who dominated the second half of the 19th century, the so-called "Golden age" of Norwegian literature.

VI.

\begin{tabular}{|c|c|}
\hline Course structure & No. \\
\hline VI.1. Lectures & \\
\hline $\begin{array}{l}\text { Lecture 1: Norway in the second half of the 19th century. A short } \\
\text { biography of Ibsen. }\end{array}$ & 1 \\
\hline $\begin{array}{l}\text { Lecture 2: Phases of Ibsen's dramaturgy. Characteristics of Ibsen's } \\
\text { realism and modernism. }\end{array}$ & 1 \\
\hline Lecture 3: Ibsen's self-exile in Germany. & 1 \\
\hline Lecture 4: Works adapted for the screen. & 1 \\
\hline Lecture 5: Ibsen's correspondence. & 1 \\
\hline Lecture 6: Ibsen's poetry. & 1 \\
\hline Total: & $\begin{array}{c}6 \\
\text { hours }\end{array}$ \\
\hline \multicolumn{2}{|l|}{ VI.2. Seminar } \\
\hline $\begin{array}{l}\text { During the seminars the supervisor and the students discuss } \\
\text { about Ibsen starting from the knowledge acquired during the }\end{array}$ & \\
\hline
\end{tabular}




\begin{tabular}{|l|c|}
\hline $\begin{array}{l}\text { lectures, comment on texts written by Ibsen, watch materials } \\
\text { related to his work. }\end{array}$ & 6 \\
Total: & hours \\
\hline \multicolumn{2}{|c|}{ VI.3. Application (if the case) } \\
\hline VI.4. Project topic (if the case) & \\
\hline
\end{tabular}

VII.

\begin{tabular}{|c|}
\hline Syllabus outline \\
\hline VII.1. Ibsen's life \\
\hline $\begin{array}{l}\text { Historical and cultural context. Awakening of national consciousness } \\
\text { through literature. Citizens' dealing with social norms. Women } \\
\text { emancipation. Introduction of parliamentarism. } \\
\text { Ibsen in Grimstad, Christiania and Bergen. His self-exile in Germany. } \\
\text { Ibsen's correspondence. }\end{array}$ \\
\hline VII.2. Ibsen's work \\
\hline $\begin{array}{l}\text { Literary phases: historical and legendary romanticism, dramatical poems, } \\
\text { bourgeois realism, psychological realism (see Ovidiu Drîmba, "Henrik } \\
\text { Ibsen, the founder of modern theatre", preface to Henrik Ibsen, Teatru, vol. } \\
\text { I-III, Editura pentru Literatura universală, Bucureşti, 1966). } \\
\text { Ibsen's poetry. }\end{array}$ \\
\hline
\end{tabular}

VIII.

\begin{tabular}{|c|c|}
\hline \multicolumn{1}{|c|}{ References } & \\
\hline Drîmba, Ovidiu, Scriitori scandinavi în cultura lumii, Casa de Editură \\
Excelsior „Multi Press”, Bucureşti, 1997 \\
Ibsen, Henrik, Teatru, vol. I-III, Editura pentru Literatură Universală, \\
Bucureşti, 1966 \\
Leon, Crina, Henrik Ibsen şi cultura germană a timpului său, Editura \\
Tehnopress, Iaşi, 2011 \\
Tomescu Baciu, Sanda, Peer Gynt şi miturile nordice, Editura Napoca Star, \\
Cluj-Napoca, 2000 \\
Vartic, Ion, Ibsen şi "teatrul invizibil”. Preludii la o teorie a dramei, Editura \\
Didactică şi Pedagogică, Bucureşti, 1995 \\
\hline
\end{tabular}

IX.

Forms of
Methods and techniques used in the teaching process




\begin{tabular}{|l|l|}
\multicolumn{1}{|c|}{ activity } & \\
\hline Lecture & Thematic lectures, PowerPoint presentations. \\
\hline Seminar & $\begin{array}{l}\text { Text analysis, interactive methods of acquiring new } \\
\text { knowledge. }\end{array}$ \\
\hline Application & \\
\hline Project & \\
\hline
\end{tabular}

$\mathrm{X}$.

\begin{tabular}{|l|l|l|}
\hline Type & $\begin{array}{l}\text { Assessment system (written, } \\
\text { written and oral, oral, others) }\end{array}$ & \\
\hline Exam & $\begin{array}{l}\text { Written examination (for the } \\
\text { lectures) }\end{array}$ & \\
\hline Colloquium & & \\
\hline $\begin{array}{l}\text { Continuous } \\
\text { assessment }\end{array}$ & $\begin{array}{l}\text { Continuous assessment (for the } \\
\text { seminars) }\end{array}$ & \\
\hline Project & & \\
\hline
\end{tabular}

I.

\begin{tabular}{|l|l|}
\hline Course title & $\begin{array}{l}\text { SCANDINAVIAN AND ROMANIAN } \\
\text { CONTRIBUTIONS TO PEACE DURING THE } \\
\text { TWENTIETH CENTURY }\end{array}$ \\
\hline
\end{tabular}

II.

\begin{tabular}{|c|c|c|c|c|}
\hline \multicolumn{5}{|c|}{$\begin{array}{c}\text { Course structure } \\
\text { (Number of hours per } \\
\text { summer school session) }\end{array}$} \\
\hline Level & Lecture & Seminar & $\begin{array}{c}\text { Practical } \\
\text { course }\end{array}$ & $\begin{array}{c}\text { Summer school } \\
\text { year }\end{array}$ \\
\hline Beginners & 6 & 6 & & $1^{\text {st }}$ \\
\hline
\end{tabular}

III.

\begin{tabular}{|l|l|c|c|}
\hline $\begin{array}{l}\text { Optionality } \\
\text { category }\end{array}$ & Imposed & Optional & Freely chosen \\
\hline & & $\mathrm{X}$ & \\
\hline
\end{tabular}

IV.

\begin{tabular}{|l|l|l|l|l|}
\hline \multicolumn{5}{|c|}{ Supervisor } \\
\hline & \multicolumn{1}{|c|}{ Lecture } & \multicolumn{1}{|c|}{ Seminar } & Application & Project \\
\hline Name & Silviu Miloiu & Silviu Miloiu & & \\
\hline Institution & Valahia & Valahia & &
\end{tabular}




\begin{tabular}{|c|c|c|}
\hline & University & University \\
\hline Department & $\begin{array}{l}\text { Depart. of } \\
\text { History }\end{array}$ & $\begin{array}{l}\text { Depart. of } \\
\text { History }\end{array}$ \\
\hline $\begin{array}{l}\text { Scientific } \\
\text { title }\end{array}$ & Ph.D. & Ph.D. \\
\hline Position & Professor & Professor \\
\hline
\end{tabular}

V.

\section{Objectives}

The course approaches and parallels the Scandinavian and Romanian contributions to peace during the Twentieth Century. Topics such as the Romanian contributions to the development of international criminal law, the Nobel Peace Prizes and Scandinavian and Romanian involvement in the promotion of collective and regional security and peacekeeping will be focused on in this course.

VI.

\begin{tabular}{|c|c|}
\hline Course structure & \multirow{2}{*}{$\begin{array}{l}\text { No. } \\
\text { hours }\end{array}$} \\
\hline VI.1. Lectures & \\
\hline Lecture 1: The Nobel Peace Prizes & 1 \\
\hline Lecture 2: The Nansen Committee for Refugees & 1 \\
\hline $\begin{array}{l}\text { Lecture 3: Romanian and Scandinavian contributions to } \\
\text { collective and regional security }\end{array}$ & 1 \\
\hline $\begin{array}{l}\text { Lecture 4: Romanian contributions to the development of } \\
\text { criminal law }\end{array}$ & 1 \\
\hline $\begin{array}{l}\text { Lecture 5: Romanian and Scandinavian contributions to } \\
\text { peacekeeping actions }\end{array}$ & 1 \\
\hline Lecture 6: Final evaluation & 1 \\
\hline Total: & $\begin{array}{c}6 \\
\text { hours }\end{array}$ \\
\hline \multicolumn{2}{|l|}{ VI.2. Seminar } \\
\hline $\begin{array}{l}\text { Readings, discussions and movies about topics approached } \\
\text { during the lectures. } \\
\text { Total: }\end{array}$ & $\begin{array}{c}6 \\
\text { hours }\end{array}$ \\
\hline VI.3. Application (if the case) & \\
\hline VI.4. Project topic (if the case) & \\
\hline
\end{tabular}

VII. 


\section{Syllabus outline}

Romanian contributions to the development of international criminal law; the Nobel Peace Prizes; Scandinavian and Romanian involvement in the promotion of collective and regional security and peacekeeping

\section{VIII.}

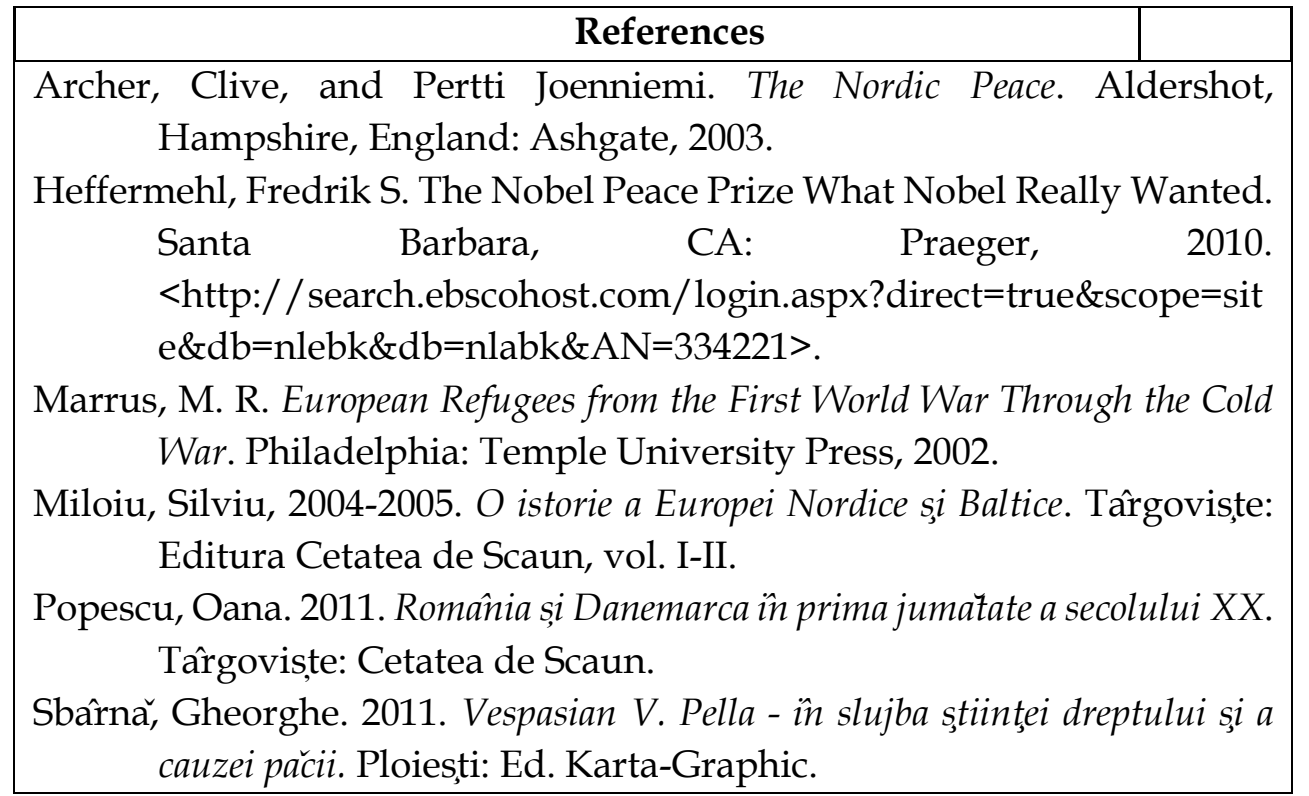

IX.

\begin{tabular}{|l|l|}
\hline \multicolumn{1}{|c|}{$\begin{array}{c}\text { Forms of } \\
\text { activity }\end{array}$} & \multicolumn{1}{|c|}{$\begin{array}{c}\text { Methods and techniques used in the } \\
\text { teaching process }\end{array}$} \\
\hline Lecture & Thematic lectures, PowerPoint presentations. \\
\hline Seminar & $\begin{array}{l}\text { Text analysis, interactive methods of acquiring new } \\
\text { knowledge. }\end{array}$ \\
\hline Application & \\
\hline Project & \\
\hline
\end{tabular}

$\mathrm{X}$.

\begin{tabular}{|l|l|l|}
\hline Type & $\begin{array}{l}\text { Assessment system (written, } \\
\text { written and oral, oral, others) }\end{array}$ & \\
\hline Exam & $\begin{array}{l}\text { Written examination (for the } \\
\text { lectures) }\end{array}$ & \\
\hline Colloquium & & \\
\hline Continuous & Continuous assessment (for the & \\
\hline
\end{tabular}




\begin{tabular}{|l|l|l|}
\hline assessment & seminars) & \\
\hline Project & & \\
\hline
\end{tabular}

I.

\begin{tabular}{|l|l|l|}
\hline Course title & $\begin{array}{l}\text { ROMANIA AND THE SCANDINAVIAN } \\
\text { COUNTRIES: CHALLENGES OF } \\
\text { SECURITY IN THE COLD WAR }\end{array}$ & \\
\hline
\end{tabular}

II.

\begin{tabular}{|c|c|c|c|c|}
\hline \multicolumn{5}{|c|}{$\begin{array}{c}\text { Course structure } \\
\text { (Number of hours per } \\
\text { summer school session) }\end{array}$} \\
\hline Level & Lecture & Seminar & $\begin{array}{c}\text { Practical } \\
\text { course }\end{array}$ & $\begin{array}{c}\text { Summer school } \\
\text { year }\end{array}$ \\
\hline Beginners & 6 & 6 & & $1^{\text {st }}$ \\
\hline
\end{tabular}

\section{III.}

\begin{tabular}{|l|l|c|c|}
\hline $\begin{array}{l}\text { Optionality } \\
\text { category }\end{array}$ & Imposed & Optional & Freely chosen \\
\hline & & $\mathrm{X}$ & \\
\hline
\end{tabular}

IV.

\begin{tabular}{|l|l|l|l|l|}
\hline \multicolumn{5}{|c|}{ Supervisor } \\
\hline & \multicolumn{1}{|c|}{ Lecture } & \multicolumn{1}{|c|}{ Seminar } & Application & Project \\
\hline Name & Cezar Stanciu & Cezar Stanciu & & \\
\hline Institution & Valahia & Valahia & & \\
& University & University & & \\
\hline Department & $\begin{array}{l}\text { Department of } \\
\text { History }\end{array}$ & $\begin{array}{l}\text { Department of } \\
\text { History }\end{array}$ & & \\
\hline Scientific title & Ph.D. & Ph.D. & & \\
\hline Position & Assistant & Assistant & & \\
\hline
\end{tabular}

V.

\section{Objectives}

- to develop the students' capacity to formulate correct assessments of the political and historical factors which determined the evolution of postwar bilateral relations between Romania and the Scandinavian countries;

- to develop the students' ability to compare different choices in matters of security relating them to existing preconditions; 
- to evaluate various options in the field of security and formulate independent points of view with regard to their viability;

- to develop the students' ability to investigate sources and elaborate critical assessments of them.

VI.

\begin{tabular}{|c|c|}
\hline Course structure & \multirow{2}{*}{$\begin{array}{l}\text { No. } \\
\text { hours }\end{array}$} \\
\hline VI.1. Lectures & \\
\hline $\begin{array}{l}\text { Lecture 1: Romania and the Scandinavian countries in the context } \\
\text { of postwar reorganization of Europe } \\
\text { Lecture 2: Neutrality or alignment as security options } \\
\text { Lecture 3: Romanian-Scandinavian cooperation in politics and } \\
\text { economy } \\
\text { Lecture 4: Political convergences: visions of détente and the role } \\
\text { of small states } \\
\text { Lecture 5: The CSCE and its aftermath } \\
\text { Lecture 6: The limits of rapprochement: incompatibilities and } \\
\text { failures } \\
\text { Total: }\end{array}$ & $\begin{array}{c}1 \\
1 \\
6 \\
\text { hours }\end{array}$ \\
\hline \multicolumn{2}{|l|}{ VI.2. Seminar } \\
\hline $\begin{array}{l}\text { 1. Premises. Bipolarity and the impact of bloc-oriented } \\
\text { policies } \\
\text { 2. Limited choices. "Nuclear umbrella" or Finlandization? } \\
\text { 3. Extended choices: trade penetrates the Iron Curtain } \\
\text { 4. Small states in a world of superpowers } \\
\text { 5. The Cold War revived: } 1975-1989 \\
\text { 6. Final evaluation }\end{array}$ & $\begin{array}{c}1 \\
1 \\
1 \\
1 \\
1 \\
6 \\
\text { hours }\end{array}$ \\
\hline VI.3. Application (if the case) & \\
\hline VI.4. P & \\
\hline
\end{tabular}

VII.

\section{Syllabus outline}

The course aims at developing student skills to evaluate various options in the field of security and formulate independent points of view with regard to their viability; 
VIII.

\begin{tabular}{|c|}
\hline References \\
\hline $\begin{array}{l}\text { Agius, Christine, The Social Construction of Swedish Neutrality: Challenges to } \\
\text { Swedish Identity and Sovereignty, Manchester University Press, } 2006\end{array}$ \\
\hline $\begin{array}{l}\text { Burakowski, Adam, Dictatura lui Nicolae Ceauşescu 1965-1989, Editura } \\
\quad \text { Polirom, Iaşi, } 2012\end{array}$ \\
\hline Karsh, Efraim, Neutrality and Small States, Routledge, London, 2012 \\
\hline $\begin{array}{c}\text { Kullaa, Rinna, Non-Alignment and its Origins in Cold War Europe: } \\
\text { Yugoslavia, Finland and the Soviet Challenge, I.B. Tauris, } 2012\end{array}$ \\
\hline $\begin{array}{l}\text { Malița, Mircea, Tablouri din războiul rece. Memorii ale unui diplomat român, } \\
\text { Editura C.H. Beck, Bucureşti, } 2007\end{array}$ \\
\hline $\begin{array}{l}\text { Miloiu, Silviu, O istorie a Europei nordice şi baltice, vol. II, Editura Cetatea } \\
\text { de Scaun, Târgovişte, } 2004\end{array}$ \\
\hline $\begin{array}{l}\text { Olesen, Thorsten B., The Cold War and the Nordic countries: historiography at } \\
\text { a crossroads, University Press of Southern Denmark, } 2004\end{array}$ \\
\hline
\end{tabular}

IX.

\begin{tabular}{|l|l|}
\hline $\begin{array}{c}\text { Forms of } \\
\text { activity }\end{array}$ & \multicolumn{1}{c|}{$\begin{array}{c}\text { Methods and techniques used in the } \\
\text { teaching process }\end{array}$} \\
\hline Lecture & Lecture, demonstration, comparison, brainstorming, \\
\hline Seminar & Brainstorming, debate, discovery, conversation, workshop \\
\hline Application & \\
\hline Project & \\
\hline
\end{tabular}

$\mathrm{X}$.

\begin{tabular}{|l|l|l|}
\hline Type & $\begin{array}{l}\text { Assessment system (written, } \\
\text { written and oral, oral, others) }\end{array}$ & \\
\hline Exam & $50 \%$ (written) & \\
\hline Colloquium & & \\
\hline $\begin{array}{l}\text { Continuous } \\
\text { assessment }\end{array}$ & $50 \%$ (oral) & \\
\hline Project & & \\
\hline
\end{tabular}

I.

\begin{tabular}{|l|l|l|}
\hline Course title & $\begin{array}{l}\text { THE FINNISH CULTURE DURING THE } \\
\text { TWENTIETH CENTURY }\end{array}$ & \\
\hline
\end{tabular}

II.

48 


\begin{tabular}{|c|c|c|c|c|}
\hline \multicolumn{5}{|c|}{$\begin{array}{c}\text { Course structure } \\
\text { (Number of hours per } \\
\text { summer school session) }\end{array}$} \\
\hline Level & Lecture & Seminar & $\begin{array}{c}\text { Practical } \\
\text { course }\end{array}$ & $\begin{array}{c}\text { Summer school } \\
\text { year }\end{array}$ \\
\hline Beginners & 6 & 6 & & 1 st \\
\hline
\end{tabular}

\section{III.}

\begin{tabular}{|l|l|c|c|}
\hline $\begin{array}{l}\text { Optionality } \\
\text { category }\end{array}$ & Imposed & Optional & Freely chosen \\
\hline & & $\mathrm{X}$ & \\
\hline
\end{tabular}

IV.

\begin{tabular}{|c|c|c|c|c|}
\hline \multicolumn{5}{|c|}{ Supervisor } \\
\hline & Lecture & Seminar & Application & Project \\
\hline Name & Elena Dragomir & $\begin{array}{l}\text { Elena } \\
\text { Dragomir }\end{array}$ & & \\
\hline Institution & $\begin{array}{l}\text { The Romanian } \\
\text { Association for } \\
\text { Baltic and } \\
\text { Nordic Studies }\end{array}$ & $\begin{array}{l}\text { The Romanian } \\
\text { Association } \\
\text { for Baltic and } \\
\text { Nordic } \\
\text { Studies }\end{array}$ & & \\
\hline Department & $\begin{array}{l}\text { Center of Baltic } \\
\text { and Nordic } \\
\text { Studies }\end{array}$ & $\begin{array}{l}\text { Center of } \\
\text { Baltic and } \\
\text { Nordic } \\
\text { Studies }\end{array}$ & & \\
\hline Scientific title & Ph.D. & Ph.D. & & \\
\hline Position & Director & Director & & \\
\hline
\end{tabular}

V.

\section{Objectives}

Students will develop:

1. Knowledge and basic understanding about:

- Finnish culture in the $20^{\text {th }}$ century, including popular culture, lifestyle, mentality, education, society, nature, and population

- Finland's culture and society in a European/global context

- Objects and practices which are associated to Finish identity and traditions (e.g. naming the national symbols of Finland, being familiar with some local celebrations or holidays, etc.). 
- interactions of persons, societies, cultures and environments across time

- continuity and change, personal and social futures and strategies for change

2. Skills to:

- investigate and engage in effective evaluation, analysis and synthesis of information

from a variety of sources

- communicate information, ideas and issues in appropriate forms to different audiences

in a variety of contexts;

3. Informed and responsible values and attitudes towards:

- intercultural understanding

- informed and active citizenship

- lifelong learning.

VI.

\begin{tabular}{|c|c|}
\hline Course structure & \multirow{2}{*}{$\begin{array}{l}\text { No. } \\
\text { hours }\end{array}$} \\
\hline VI.1. Lectures & \\
\hline Lecture 1: Introduction to Finland and its culture & 2 \\
\hline Lecture 2: Finnish literature, folk culture and national epic & 1 \\
\hline 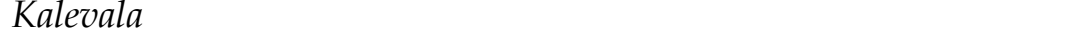 & \\
\hline Lecture 3: Education, press, radio, and sport in Finland & 1 \\
\hline $\begin{array}{l}\text { Lecture 4: Visual art, music, film, sculpture, architecture and } \\
\text { design in Finland }\end{array}$ & 1 \\
\hline $\begin{array}{l}\text { Lecture 5: Views to Finnish culture: stereotypes, identities, way } \\
\text { of life, traditions }\end{array}$ & 1 \\
\hline Total: & hours \\
\hline \multicolumn{2}{|l|}{ VI.2. Seminar } \\
\hline $\begin{array}{l}\text { Seminar 1: Introduction to Finland and its culture } \\
\text { Seminar 2: Finnish literature, folk culture and national epic } \\
\text { Kalevala } \\
\text { Seminar 3: Education, press, radio, and sport in Finland } \\
\text { Seminar 4: Visual art, music, film, sculpture, architecture and } \\
\text { design in Finland }\end{array}$ & $\begin{array}{l}1 \\
1\end{array}$ \\
\hline
\end{tabular}




\begin{tabular}{|c|c|}
\hline $\begin{array}{l}\text { Seminar 5: Views to Finnish culture: stereotypes, identities, way } \\
\text { of life, traditions } \\
\text { Final evaluation }\end{array}$ & $\begin{array}{c}1 \\
1 \\
6 \\
\text { hours }\end{array}$ \\
\hline $\begin{array}{l}\text { VI.4. Project topic (if the case) } \\
\text { Students will choose an interesting topic about the Finnish } \\
\text { culture and will prepare a presentation about it. } \\
\text { Possible topics: } \\
\text { A Finnish writer, architect, designer, film maker etc. } \\
\text { A Finnish work of art (sculpture, painting, novel, poetry, } \\
\text { building, etc.) } \\
\text { Finnish traditions, customs and celebrations (Easter, Christmas, } \\
\text { Midsummer celebrations etc.) }\end{array}$ & \\
\hline
\end{tabular}

VII.

\section{Syllabus outline}

Students will explore the Nordic country through texts, stories, historical events, movies, literature and arts. The aim is to learn what Finland is like and has been like as a nation and understand the cultural characteristics of the area. Students are encouraged to use analytical, creative and critical thinking to understand and respect the Finnish way of life.

VIII.

\begin{tabular}{|c|c|c|}
\hline \multicolumn{3}{|c|}{ References } \\
\hline \multicolumn{3}{|c|}{$\begin{array}{l}\text { Elena Dragomir, Silviu Miloiu, Istoria Finlandei, Ed. Cetatea de Scau } \\
\text { Târgoviște, } 2011 .\end{array}$} \\
\hline \multicolumn{3}{|c|}{ IX. } \\
\hline $\begin{array}{l}\text { Forms of } \\
\text { activity }\end{array}$ & $\begin{array}{l}\text { Methods and techniques used in the } \\
\text { teaching process }\end{array}$ & \\
\hline Lecture & & \\
\hline
\end{tabular}




\begin{tabular}{|l|l|}
\hline Seminar & $\begin{array}{l}\text { Students will explore the Nordic country through texts, } \\
\text { stories, historical events, movies, literature and arts. The aim } \\
\text { is to learn what Finland is like and has been like as a nation } \\
\text { and understand the cultural characteristics of the area. } \\
\text { Students are encouraged to use analytical, creative and } \\
\text { critical thinking to understand and respect the Finnish way } \\
\text { of life. } \\
\text { Student will compare the Finnish culture with other cultures } \\
\text { in European/global context. }\end{array}$ \\
\hline Project & $\begin{array}{l}\text { Students will choose an interesting topic about the Finnish } \\
\text { culture and will prepare a presentation about it. }\end{array}$ \\
\hline
\end{tabular}

X.

\begin{tabular}{|l|l|l|}
\hline Type & $\begin{array}{l}\text { Assessment system (written, } \\
\text { written and oral, oral, others) }\end{array}$ & \\
\hline $\begin{array}{l}\text { Attendance } \\
\text { and class } \\
\text { participation: }\end{array}$ & $50 \%$ & \\
\hline $\begin{array}{l}\text { Individual } \\
\text { assignment/ } \\
\text { Project: }\end{array}$ & $50 \%$ & \\
\hline
\end{tabular}

I.

\begin{tabular}{|l|l|l|}
\hline Course title & $\begin{array}{l}\text { SCANDINAVIA - NATURE, MAN, } \\
\text { ECONOMY }\end{array}$ & \\
\hline
\end{tabular}

II.

\begin{tabular}{|c|c|c|c|c|}
\hline \multicolumn{5}{|c|}{$\begin{array}{c}\text { Course structure } \\
\text { (Number of hours per } \\
\text { summer school session) }\end{array}$} \\
\hline Level & Lecture & Seminar & $\begin{array}{c}\text { Practical } \\
\text { course }\end{array}$ & $\begin{array}{c}\text { Summer school } \\
\text { year }\end{array}$ \\
\hline Beginners & 10 & 2 & & $1^{\text {st }}$ \\
\hline
\end{tabular}

\section{III.}

\begin{tabular}{|l|l|c|c|}
\hline $\begin{array}{l}\text { Optionality } \\
\text { category }\end{array}$ & Imposed & Optional & Freely chosen \\
\hline & & $\mathrm{X}$ & \\
\hline
\end{tabular}

IV. 


\begin{tabular}{|l|l|l|l|l|}
\hline \multicolumn{5}{|c|}{ Supervisor } \\
\hline & \multicolumn{1}{|c|}{ Lecture } & \multicolumn{1}{c|}{ Seminar } & Application & Project \\
\hline Name & Daniela Larion & $\begin{array}{l}\text { Daniela } \\
\text { Larion }\end{array}$ & & \\
\hline Institution & $\begin{array}{l}\text { Al. I. Cuza } \\
\text { University of } \\
\text { Iasi }\end{array}$ & $\begin{array}{l}\text { Al. I. Cuza } \\
\text { University of } \\
\text { Iasi }\end{array}$ & & \\
\hline Department & Geography & Geography & & \\
\hline Scientific title & Ph.D. & Ph.D. & & \\
\hline Position & Lecturer & Lecturer & & \\
\hline V. & & & & \\
\hline
\end{tabular}

V.

\section{Objectives}

- to understand the natural elements of the Scandinavian environment, their interdependence and interference in generation the unique landscape of Scandinavia

- to use the physical and human geographical elements in describing different areas in Scandinavia

- to explain the regional differences in the demography and economy of Scandinavia

- to elaborate studies on the environmental changes in different regional spaces (causes and consequences)

VI.

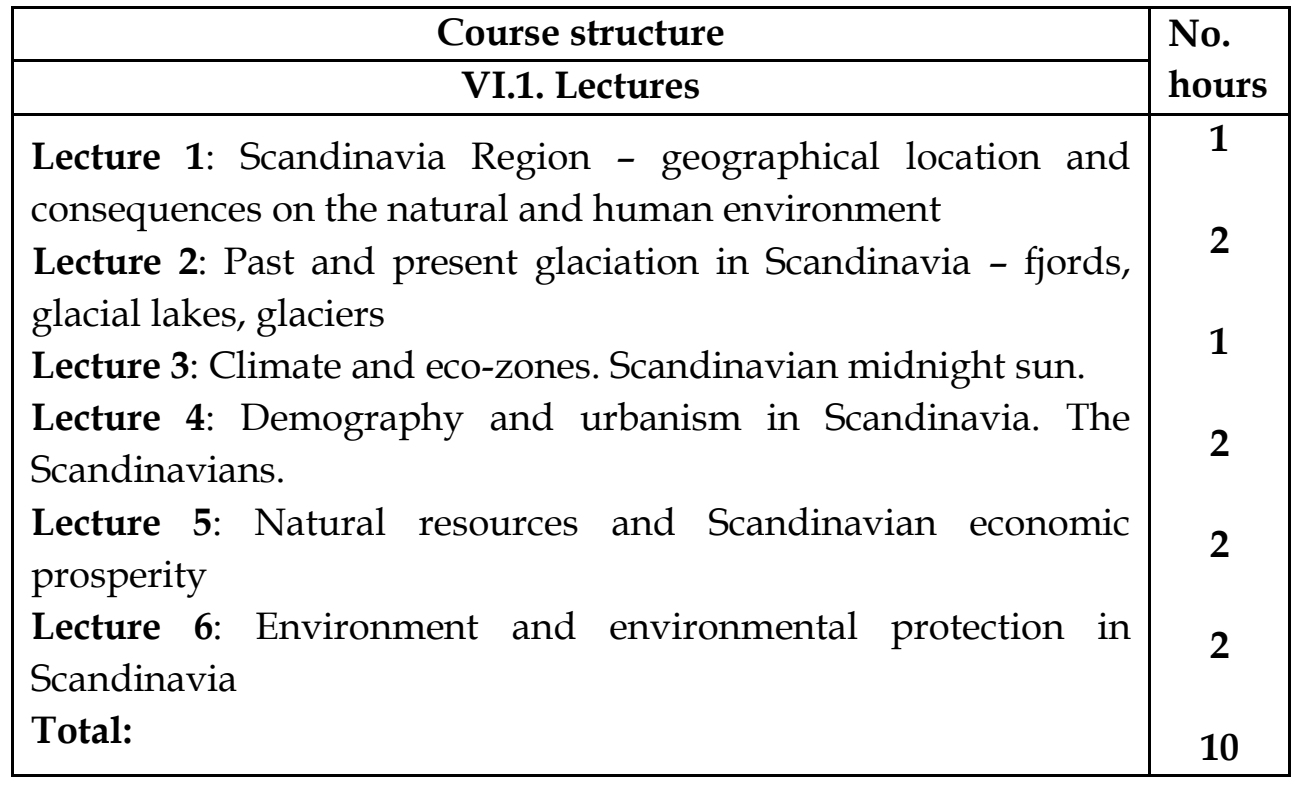




\begin{tabular}{|c|c|}
\hline & hours \\
\hline \multicolumn{2}{|l|}{ VI.2. Seminar } \\
\hline Map of Scandinavia (physical aspects) - practical activity & 1 \\
\hline Map of Scandinavia (human aspects) - practical activity & 1 \\
\hline Total: & $\begin{array}{c}2 \\
\text { hours }\end{array}$ \\
\hline VI.3. Application (if the case) & \\
\hline VI.4. Project topic (if the case) & \\
\hline
\end{tabular}

VII.

\section{Syllabus outline}

Geographical terms (in the fields of regional geography, climatology, hydrology, geomorphology, glaciology, environment, human, social and economic geography)

\section{VIII.}

\begin{tabular}{|l|}
\hline \multicolumn{1}{|c|}{ References } \\
\hline 1. Larion D. (2005) - Geografia continentelor - Europa , Editura Azimuth, Iaşi \\
2. Larion D. (2010) - Geografia mediilor temperate si reci - Editura PIM, Iasi \\
3. Neguț S. et al (2001) - Enciclopedia Europei, Editura Meronia, Bucureşti \\
4. Neguț S. et al (1995, 1998, 2003) - Statele lumii, Bucuresti \\
5. XXX (1994) - World Reference Atlas, Teknologisk Forlag, Oslo \\
6. XXX (1995 - 2010) - Calendario Atlante de Agostini \\
7. XXX (2008) - Geografica - Enciclopedia si Atlasul Lumii, Editura Ullmann, \\
Roma. \\
8. XXX (1980 - 2012) - National Geographic \\
\hline
\end{tabular}

IX.

\begin{tabular}{|c|c|}
\hline & $\begin{array}{l}\text { Methods and techniques used in the } \\
\text { teaching process }\end{array}$ \\
\hline Lecture & $\begin{array}{l}\text { Interactive power point presentations; conversation; } \\
\text { problematization; debate }\end{array}$ \\
\hline Seminar & Use of diagrams and graphical representations; \\
\hline Application & \\
\hline Project & Geographical research methods \\
\hline $\bar{X}$. & \\
\hline Type & $\begin{array}{l}\text { Assessment system } \\
\text { (written, written and oral, }\end{array}$ \\
\hline
\end{tabular}




\begin{tabular}{|l|l|l|}
\hline & oral, others) & \\
\hline Exam & & \\
\hline Colloquium & & \\
\hline $\begin{array}{l}\text { Continuous } \\
\text { assessment }\end{array}$ & $50 \%$ & \\
\hline Project & $50 \%$ & \\
\hline
\end{tabular}

I.

\begin{tabular}{|l|l|l|}
\hline Course title & NORWAY AS A TOURIST & \\
& DESTINATION FOR THE ROMANIAN & \\
& TRAVELLERS DURING THE & \\
& INTERWAR PERIOD & \\
\hline
\end{tabular}

II.

\begin{tabular}{|c|c|c|c|c|}
\hline \multicolumn{5}{|c|}{$\begin{array}{c}\text { Course structure } \\
\text { (Number of hours per } \\
\text { summer school session) }\end{array}$} \\
\hline Level & Lecture & Seminar & $\begin{array}{c}\text { Practical } \\
\text { course }\end{array}$ & $\begin{array}{c}\text { Summer school } \\
\text { year }\end{array}$ \\
\hline Beginners & 12 & & & $1^{\text {st }}$ \\
\hline
\end{tabular}

\section{III.}

\begin{tabular}{|l|l|c|l|}
\hline $\begin{array}{l}\text { Optionality } \\
\text { category }\end{array}$ & Imposed & Optional & Freely chosen \\
\hline & & $\mathrm{X}$ & \\
\hline
\end{tabular}

IV.

\begin{tabular}{|l|l|l|l|l|}
\hline \multicolumn{5}{|c|}{ Supervisor } \\
\hline & \multicolumn{1}{|c|}{ Lecture } & Seminar & Application & Project \\
\hline Name & Ana - Maria Despa & & & \\
\hline Institution & $\begin{array}{l}\text { Valahia Univ. } \\
\text { Targoviste/ARSBN }\end{array}$ & & & \\
\hline Department & Dept. of History & & & \\
\hline $\begin{array}{l}\text { Scientific } \\
\text { title }\end{array}$ & Ph.D. & & & \\
\hline Position & & & & \\
\hline
\end{tabular}

V.

\section{Objectives}

- $\quad$ To be able to distinguish between various historical sources; 
- To be able to explain the factors behind Norway's image as a tourist destination for the Romanian travellers during the interwar period;

- To manifest a positive attitude towards the Romanian - Norwegian cultural relations during the interwar period;

VI.

\begin{tabular}{|l|l|}
\hline \multicolumn{1}{|c|}{ Course structure } & $\begin{array}{l}\text { No. } \\
\text { of } \\
\text { hours }\end{array}$ \\
\hline \multicolumn{1}{|c|}{ VI.1. Lectures } & \\
Lecture 1: Introduction & Formation process of mutual perceptions and images \\
Lecture 3: Norway as a tourist destination for the Romanian \\
travellers. Items of Interest (part 1) \\
Lecture 4: Norway as a tourist destination for the Romanian \\
travellers. Items of Interest (part 2) \\
$\begin{array}{l}\text { Lecture 5: Tourism in Norway in the interwar period. Costs, } \\
\text { routes and social prestige }\end{array}$ \\
$\begin{array}{l}\text { Lecture 6: Romanian travellers in Norway between 1936 - 1939. } \\
\text { Case study }\end{array}$ \\
Lecture 7: Norway as a tourist destination for the Romanian \\
travellers in the first half of the 20th century (part 1) \\
Lecture 8: Norway as a tourist destination for the Romanian \\
travellers in the first half of the 20th century (part 2) \\
Lecture 9: Norway as a tourist destination for the Romanian \\
travellers in the first half of the 20th century (part 3) \\
Lecture 10: Norway seen as a model by the Romanian travellers \\
in the first half of the 20th century \\
Lecture 11: Norwegian perceptions on Romania during the half \\
of the 20th century \\
Lecture 12: Conclusion. Final evaluation \\
Total: 12
\end{tabular}

VII.

Lecture 1: Introduction

Syllabus outline 
- Historical sources: diplomatic documents, travel literature, travel notes, newspapers, graphics;

- The role of travel literature in the formulation and dissemination of Norway's image as a tourist destination for the Romanian travellers;

Lecture 2: Formation process of mutual perceptions and images

- Short presentation of Romanian - Norwegian relations during the interwar period;

- Key factors in forming the mutual perceptions and images between Romania and Norway;

- Imagology. Definitions;

Lecture 3: Norway as a tourist destination for the Romanian travellers. Items of Interest (part 1)

- Polar expedition: Fridtjof Nansen, Roald Amundsen;

- Svalbard Archipelago (Spitsbergen Island);

- North Cape;

Lecture 4: Norway as a tourist destination for the Romanian travellers. Items of Interest (part 2)

- Aurora Borealis;

- Midnight Sun;

- Norwegian fjords;

- Indigenous population;

Lecture 5: Tourism in Norway in the interwar period. Costs, routes and social prestige

- Tourism as a social behaviour;

- Travel costs and routes;

Lecture 6: Romanian travellers in Norway between 1936 - 1939. Case study

- Diplomatic documents vs. Travel literature;

- Period relevance for the course topic; 
- The assessment criteria: purpose, residence, occupation, sights visited by the Romanians who travelled to Norway between 1936 - 1939;

Lecture 7: Norway as a tourist destination for the Romanian travellers in the first half of the $20^{\text {th }}$ century (part 1 )

- Romanian travel literature about Norway - landscape and geographical aspects;

- Romanian travel literature about Norway - historical and cultural aspects;

Lecture 8: Norway as a tourist destination for the Romanian travellers in the first half of the 20 2 th century (part 2)

- Romanian travel literature about Norway - economical aspects;

Lecture 9: Norway as a tourist destination for the Romanian travellers in the first half of the $20^{\text {th }}$ century (part 3)

- Romanian travel literature about Norway - educational aspects;

Lecture 10: Norway seen as a model by the Romanian travellers in the first half of the $20^{\text {th }}$ century

- Early Romanian perception on the Norwegian social - political realities;

- First Romanian attempt to borrow and deploy some of the social and educational Nordic features;

Lecture 11: Norwegian perceptions on Romania during the half of the $20^{\text {th }}$ century

- Various positive and negative Norwegian perceptions on Romania;

Lecture 12: Conclusion. Final evaluation

Total: 12

VIII.

References 
1. Riksarkivet, S-2669 - Utenriksstasjonene, Legasjonen/ Ambassaden i Bucuresti, Romania.

2. Riksarkivet, S-2259 - Utenriksdepartementet.

3. Riksarkivet, Kungl. Utrikesdepartementet, B-avd. 2, vol. 107, B-1 K/Eru, Norges intressen i Romania 1942.

\section{A. Newspapers}

1. Aftenposten (iulie - august 1924, august 1930, august 1932, noiembrie - decembrie 1933, mai - octombrie 1934, martie - mai 1935, martie - aprilie 1936, iulie 1937, noiembrie 1938, iunie ianuarie 1939).

2. Dimineața (aprilie 1936).

3. L'Independance Roumain (septembrie - decembrie 1922, martie 1924, aprilie 1936)

4. Tidens Tegn (ianuarie, noiembrie, decembrie 1919, iulie 1928, august 1932, decembrie 1933, august 1934, mai 1935, aprilie 1936, februarie, iulie 1939).

5. Ziarul călătoriilor și al întâmplărilor de pe mare și uscat (noiembrie 1897 - decembrie 1939).

\section{B. Books and articles}

4. Butculescu, Nicoale, O călătorie spre Nord. Scoția, Irlanda, Spitzberg, Norvegia, Editura Universul, București, 1937.

5. Constantinescu, I. Stelian, Schițe din Norvegia. Insemnări dintr-o călătorie în ținuturile nordice cu zece reproduceri după natură. Coperta și vignete de pictorul Tonitza, Editura Al. A Stănciulescu, București, 1920.

6. Cioflec, Romulus, Sub soarele polar. Impresii și peripeții din voiajul unor salvați dela naufragiu de spărgătorul Krasin cu ilustrații, Editura Națională, București, 1932.

7. Conea Ioan, Din Norvegia, Editura Cartea Românească.

8. Gunnar, Flood, Notele unui ofițer norvegian înaintea și în timpul Războiului de Neatârnare 1876 - 1878, ediție de Radu R. Rosetii, în Miloiu Silviu, O concepție românească a Nordului sec. XIX - XX, vol. I, Editura Cetatea de Scaun, Târgoviște, 2009.

9. Iorga, Nicolae, Pe drumuri depărtate, vol. II, Editura Minerva, București, 1987 (ediție Valeriu Râpeanu). 
10. Iurașcu, Dimitrie, Rugina toamnei. Mărturii de diplomat din vremuri apuse, Ediție îngrijită și note de ing. Niculae Iurașcu, Editura Partener, Galați, 2012.

11. Miloiu, Silviu, Nicolae Iorga - Țări Scandinave: Suedia și Norvegia: note de drum și conferințe, Editura Valahia University Press, Târgoviște, 2008.

12. Negru, Mihail, Europa în zbor în 80 de ore. Raidul continental al avionului România - Sfânta Maria. Jurnal de bord, Editura Universul, București, 1929.

13. Novian, Radu, Școala și Biserica în Norvegia, București, 1904.

14. Smara, Conferințe și Discursuri, Editura Universul, București, 1905.

15. Smara, O româncă spre Polul Nord, Editura Universul, București, 1932.

16. Ștefan, C. Ioan, O călătorie la Spitzberg (cu 15 ilustrațiuni fotografice), București, 1916.

17. *** Tragedia de la Polul Nord. Destăinuiri senzaționale asupra expediției Nobile, Atelierele Adevărul, București, 1930

IX.

\begin{tabular}{|l|l|}
\hline \multicolumn{1}{|c|}{$\begin{array}{c}\text { Forms of } \\
\text { activity }\end{array}$} & \multicolumn{1}{|c|}{$\begin{array}{c}\text { Methods and techniques used in the } \\
\text { teaching process }\end{array}$} \\
\hline Lecture & $\begin{array}{l}\text { Lecturing, expository, discovery, brainstorming, mind } \\
\text { mapping. }\end{array}$ \\
\hline Seminar & \\
\hline Application & \\
\hline Project & \\
\hline
\end{tabular}

$\mathrm{X}$.

\begin{tabular}{|l|l|l|}
\hline Type & $\begin{array}{l}\text { Assessment system } \\
\text { (written, written and oral, } \\
\text { oral, others) }\end{array}$ & \\
\hline Exam & written & \\
\hline Colloquium & & \\
\hline $\begin{array}{l}\text { Continuous } \\
\text { assessment }\end{array}$ & Oral & \\
\hline Project & & \\
\hline
\end{tabular}

I. 


\begin{tabular}{|c|c|}
\hline Course title & $\begin{array}{l}\text { THE MINORITY POLICIES IN ROMANIA AND } \\
\text { THE NORDIC AREA } \\
\text { FROM WORLD WAR II TO PRESENT TIMES }\end{array}$ \\
\hline
\end{tabular}

II.

\begin{tabular}{|c|c|c|c|c|}
\hline \multicolumn{5}{|c|}{$\begin{array}{c}\text { Course structure } \\
\text { (Number of hours per } \\
\text { summer school session) }\end{array}$} \\
\hline Level & Lecture & Seminar & $\begin{array}{c}\text { Practical } \\
\text { course }\end{array}$ & $\begin{array}{c}\text { Summer school } \\
\text { year }\end{array}$ \\
\hline Beginners & 6 & 6 & & $1^{\text {st }}$ \\
\hline
\end{tabular}

III.

\begin{tabular}{|l|l|c|c|}
\hline $\begin{array}{l}\text { Optionality } \\
\text { category }\end{array}$ & Imposed & Optional & Freely chosen \\
\hline & & $\mathrm{X}$ & \\
\hline
\end{tabular}

IV.

\begin{tabular}{|c|c|c|c|c|}
\hline \multicolumn{5}{|c|}{ Supervisor } \\
\hline & Lecture & Seminar & Application & Project \\
\hline Name & $\begin{array}{l}\text { Bogdan- } \\
\text { Alexandru } \\
\text { Schipor and } \\
\text { Magdalena } \\
\text { Ionescu }\end{array}$ & & & \\
\hline Institution & $\begin{array}{l}\text { A.D. Xenopol } \\
\text { Institute of } \\
\text { History of } \\
\text { Romanian } \\
\text { Academy and } \\
\text { Valahia } \\
\text { University }\end{array}$ & & & \\
\hline \multicolumn{5}{|l|}{ Department } \\
\hline $\begin{array}{l}\text { Scientific } \\
\text { title }\end{array}$ & Ph.D. & & & \\
\hline Position & researchers & & & \\
\hline
\end{tabular}

V.

\section{Objectives}


The course aims to discuss the developments of minority policies in both the North and Romania since the outbreak of Second World War, provide an overview of the way of life, and the traditions of less known minorities (eg sami, kven). The course also aims to provide an adequate definition of concepts of minority and majority, Roma policies, but also of understanding the position of the Nordic countries towards the new minorities (immigrants).

VI.

\begin{tabular}{|c|c|}
\hline Course structure & \multirow{2}{*}{$\begin{array}{l}\text { No. } \\
\text { hours }\end{array}$} \\
\hline VI.1. Lectures & \\
\hline $\begin{array}{l}\text { Lecture 1: Repatriation of German minority from the Romanian } \\
\text { territory in } 1939 \text { - } 1940 .\end{array}$ & 1 \\
\hline Lecture 2: The repatriation of Baltic Germans, 1939-1941 & 1 \\
\hline $\begin{array}{l}\text { Lecture 3: Deportation to the Soviet Union. Administration and } \\
\text { everyday life in labor camps }\end{array}$ & 1 \\
\hline Lecture 4: Status of Minorities in Romania and the Baltic States: & 1 \\
\hline $\begin{array}{l}\text { What is a minority? Minority vs. majority; Ethnic minorities vs. } \\
\text { national minorities; Minority policies in Romania between 1945- } \\
\text { 1989; Analysis of minority-majority relations in the Baltic States } \\
\text { during 1944/1945-1990; Majorities resistance to minority policies } \\
\text { ("Forest Brothers") }\end{array}$ & \\
\hline Lecture 5: Integration of minorities in the Scandinavian space; & 1 \\
\hline $\begin{array}{l}\text { Sami - a brief introduction; Roma in the North - from } \\
\text { discrimination to tolerance; Participation of minorities in public } \\
\text { decision-making (Swedes in Finland, Germans in Denmark) }\end{array}$ & \\
\hline Lecture 6: EU enlargement and new national minorities & $\mathbf{1}$ \\
\hline Total: & $\begin{array}{c}6 \\
\text { hours }\end{array}$ \\
\hline \multicolumn{2}{|l|}{ VI.2. Seminar } \\
\hline $\begin{array}{l}\text { Readings, discussions and movies about the topics approached } \\
\text { during the lectures. } \\
\text { Total: }\end{array}$ & $\begin{array}{c}6 \\
\text { hours }\end{array}$ \\
\hline VI.3. Application (if the case) & \\
\hline VI.4. Project topic (if the case) & \\
\hline
\end{tabular}


VII.

\begin{tabular}{|l|}
\hline \multicolumn{1}{|c|}{ Syllabus outline } \\
\hline Repatriation of Germans from the Baltic countries; deportations in the \\
Soviet Union, the status of minorities in Romania and the Baltic States, \\
Scandinavian spatial integration of minorities; widening U.E. and new \\
national minorities
\end{tabular}

\section{VIII.}

\begin{tabular}{|c|c|c|}
\hline \multicolumn{3}{|c|}{ References } \\
\hline \multicolumn{3}{|c|}{$\begin{array}{l}\text { Dixon, John, Robert P. Scheurell, 1995. Social Welfare with Indigenous } \\
\text { Peoples, Routledge, London }\end{array}$} \\
\hline \multicolumn{3}{|c|}{$\begin{array}{c}\text { Miloiu, Silviu, 2004-2005. O istorie a Europei N } \\
\text { Editura Cetatea de Scaun, vol. I-II. }\end{array}$} \\
\hline \multicolumn{3}{|c|}{$\begin{array}{l}\text { *** 2004.Finland's Romani People, Ministry of Social Affairs and Health, } \\
\text { Helsinki }\end{array}$} \\
\hline \multicolumn{3}{|c|}{$\begin{array}{l}\text { Berdichevsky, Norman,2004. Nations, language and citizenship, North } \\
\text { Carolina, S.U.A., McFarland \& Company }\end{array}$} \\
\hline \multicolumn{3}{|l|}{$\mathbf{X}$} \\
\hline $\begin{array}{l}\text { Forms of } \\
\text { activity }\end{array}$ & $\begin{array}{l}\text { Methods and techniques used in the } \\
\text { teaching process }\end{array}$ & \\
\hline Lecture & Thematic lectures, PowerPoint presentations. & \\
\hline Seminar & $\begin{array}{l}\text { Text analysis, interactive methods of acquiring new } \\
\text { knowledge. }\end{array}$ & \\
\hline \multicolumn{3}{|l|}{ Application } \\
\hline Project & & \\
\hline
\end{tabular}

$\mathrm{X}$.

\begin{tabular}{|l|l|l|}
\hline Type & $\begin{array}{l}\text { Assessment system (written, } \\
\text { written and oral, oral, others) }\end{array}$ & \\
\hline Exam & $\begin{array}{l}\text { Written examination (for the } \\
\text { lectures) }\end{array}$ & \\
\hline Colloquium & & \\
\hline $\begin{array}{l}\text { Continuous } \\
\text { assessment }\end{array}$ & $\begin{array}{l}\text { Continuous assessment (for the } \\
\text { seminars) }\end{array}$ & \\
\hline Project & & \\
\hline
\end{tabular}

